\title{
Response of Land Use Change to the Grain for Green Program and Its Driving Forces in the Loess Hilly-Gully Region
}

\author{
Xiao Zhang ${ }^{1,2} \mathbb{D}^{\text {, Yuanjie Deng }}{ }^{1,2} \mathbb{C}^{\text {, Mengyang Hou }}{ }^{1,2}$ and Shunbo Yao ${ }^{1,2, *}$ \\ 1 College of Economics and Management, Northwest A\&F University, Yangling 712100, China; \\ xiao.zhang9@uqconnect.edu.au (X.Z.); dengyuanjie@nwafu.edu.cn (Y.D.); \\ houmengyang@nwafu.edu.cn (M.H.) \\ 2 Center for Resource Economics and Environment Management, Northwest A\&F University, Yangling 712100, \\ China \\ * Correspondence: yaoshunbo@nwafu.edu.cn
}

check for updates

Citation: Zhang, X.; Deng, Y.; Hou, M.; Yao, S. Response of Land Use Change to the Grain for Green Program and Its Driving Forces in the Loess Hilly-Gully Region. Land 2021, 10, 194. https://doi.org/10.3390/ land10020194

Academic Editor: Ioannis Manakos

Received: 30 January 2021

Accepted: 10 February 2021

Published: 14 February 2021

Publisher's Note: MDPI stays neutral with regard to jurisdictional claims in published maps and institutional affiliations.

Copyright: (c) 2021 by the authors. Licensee MDPI, Basel, Switzerland. This article is an open access article distributed under the terms and conditions of the Creative Commons Attribution (CC BY) license (https:/ / creativecommons.org/licenses/by/ $4.0 /)$.
Abstract: Implementation of the Grain for Green program (GGP) intensifies land use/cover change (LUCC) in the loess hilly-gully region. Clarifying the response of LUCC to the GGP and its driving forces are basic premises to implement the GGP more effectively for alleviating soil erosion in this region. This study analyzed the spatio-temporal characteristics of conversion of cultivated land to forest land and grassland in two study periods of 2000-2010 and 2010-2018. The transition matrix model and the dynamic degree model were utilized to explore changes among cultivated land, forest land, and grassland based on the remote sensing (RS) and monitoring data of land use in 2000, 2010, and 2018. Secondly, further detection on driving forces of increase of forest land and grassland was conducted through the logistic regression model. Fourteen driving factors were selected: the GGP, elevation, slope, population density, GDP per land area, distance to city, distance to residential area, etc. The results revealed that: (1) Area of cultivated land was mainly transferred to forest land and grassland during two study periods. The conversion of cultivated land to forest land and grassland occupied $21.48 \%$ and $68.01 \%$ of outward-transferring area of cultivated land from 2000 to 2010 , and accounted for $13.26 \%$ and $74.3 \%$ from 2010 to 2018; (2) From the results of the logistic regression model, elevation, the GGP, annual mean temperature, slope III $\left(6-15^{\circ}\right)$, and GDP per land area were the main driving forces from 2000 to 2010. Moreover, the most prominent driving forces were the GGP, elevation, rural population density, slope III $\left(6-15^{\circ}\right)$, and soil pH from 2010 to 2018 . The findings of this study can help us better understand the conversion of cultivated land to forest land and grassland under the GGP and provide a scientific basis to facilitate sustainable development of land resources in the study area.

Keywords: The Grain for Green Program (GGP); conversion of cultivated land to forest and grassland; driving forces; logistic regression model; the loess hilly-gully region

\section{Introduction}

Due to soaring population growth and economic development, increasing demands for land resources, along with excessive consumption of virgin forests and grasslands, has resulted in overly rapid transformation of land cover and irreversible degradation of the ecological environment [1-3]. A deteriorated environment not only causes decline of regional land productivity, but also imposes risks on social economy and people's livelihoods $[2,4]$. In order to address these environmental problems and ensure security of food and life for human beings, the Chinese government has carried out a series of ecological restoration projects [5]. Among them, the GGP with the largest scale and highest level of participation, was piloted in Sichuan, Shaanxi, and Gansu in 1999. It was officially launched nationwide in 2002, and a new round of this project was restarted from 2014 [6,7]. The aim of implementing this project was to slow down water and soil erosion and improve rate of vegetation cover by converting cultivated land on steep slopes to either forest or 
grassland [4,8]. By 2018, nearly 133,333 ha of cultivated land had been gradually converted to forest land and grassland, and total investment has reached 500 billion yuan [9]. Later, research revealed that the GGP has made remarkable achievements in alleviating soil erosion and sandstorm $[8,10,11]$, reversing the trend of ecological deterioration, and promoting harmonious development between humans and nature through 20 years of construction [12-14]. This ecological restoration project will lead to large-scale, transformational land use changes and produce profound environmental and socio-economic impacts at both regional and national scales [15]. Furthermore, land use/cover change (LUCC) is a focal issue of global environmental change and sustainability since it is closely related to nature and human activities, influencing the sustainable development of cities, societies, and people's daily life [16-19]. However, the impact of the GGP on LUCC remains largely unknown at the regional scale since recent studies did not focus enough on the new-round implementation of the GGP. Therefore, it is essential to explore the impact of the GGP on the process of land use change for understanding and assessing the effectiveness of large-scale ecological restoration efforts at both regional and national scales.

Scholars have conducted numerous researches on the impact of the GGP on LUCC. Some scholars selected specific research areas and established calculation models of land use change to conduct related studies. Specifically, changing situations, rationality, and development of land use and cover and landscape characteristics of different regions after implementing the GGP were explored [20-24]. Moreover, some scholars analyzed spatial distribution and change trajectory of land use in the area based on background of the GGP's implementation, assessed its impact on landscape architecture, vegetation cover, carbon sequestration capacity, soil erosion and other ecological benefits before and after the implementation of the project, and discovered that launching the GGP can not only influence LUCC, but also increase vegetation coverage rate, increase carbon sink reserves, and significantly improve the effect of soil and water conservation [14,25-28]. In addition, the implementation of this project has improved the efficiency of ecosystem management to meet the needs of protecting the ecological environment, promote more effective land resource planning and management, and alleviate the conflict between humans and land [24] In summary, previous studies used natural science, Geographic Information Systems (GIS) and RS technology as tools to study the conversion of cultivated land to forest land and grassland, which can reflect change dynamics, magnitude, and intensity of land use more objectively, truly, and intuitively. The above-mentioned researches have also affirmed the benefits of the GGP, and provided scientific and reasonable suggestions for the development of land policy, sustainable use of land resources, and subsequent implementation of the GGP. However, most studies only focused on the first round of the GGP and its impact on land use change (2002-2014), and did not delve into the impact of the second round of the project (2014 till now) on LUCC [20-24]. Therefore, it is impossible to learn about changes in land use caused by the second round of the GGP to evaluate the implementation effect of this project. It is also unable to provide a theoretical foundation and application value for the improvement of a new round of the GGP. In addition, most studies regarded the ecological conversion of cultivated land as the macro-background of analysis, only analyzed land use change in terms of quantity and spatial distribution, and lacked attention to regional land-use change and their driving factors. Figuring out the law of regional land use change and its influencing factors is particularly important for rational use of land resources and the sustainable development of ecological environments.

In order to further explore the driving mechanism of land use change under influence of the GGP, scholars described spatio-temporal changes of land use first, and by constructing practical econometric models to explore the driving factors of different land use types based on the background of the GGP. Topics including the spatial pattern and driving forces of land use change in China, the driving forces of the GGP at different scales, the pattern evolution and internal driving mechanism of the GGP, the characteristics and influencing factors of cultivated land before and after ecological restoration, and the impact of the policy driving force of the GGP on land use changes has been explored [24,29-32]. The study 
results show that the policy of GGP drove land use to change, which not only depended on implementation status of the project, but was also affected by local economic development level, demographic and social factors, and natural conditions [4]. Due to the fixed land base and different demands of various production activities for land resources, the direction and scale of LUCC caused by the above driving factors may also be different [33]. In summary, scholars analyzed the driving factors of land use change caused by the GGP, provided a basis to balance the process of urbanization and ecological restoration, and construct a sustainable land use structure and optimization model of typical regions [24,29-32]. However, regional land use changes are affected by a combination of social, economic, natural, geographical factors, and the GGP [4]; scholars did not further explore other factors and mechanisms that lead to spatio-temporal differences in land use changes based on their prior studies [34]. At the same time, these studies failed to measure the contribution of the policy of the GGP to regional land use changes effectively; it is impossible to effectively estimate whether it is a natural factor or a policy factor of the GGP that has an impact on the change of land use in this region.

This study mainly aimed at analyzing the response of land use change to impact of the GGP and driving forces of conversion from cultivated land to forest land and grassland in the loess hilly-gully region of two study periods-2000-2010 and 2010-2018. To achieve this goal, we first evaluated land use changes after implementation of two rounds of the GGP. Second, the logistic regression model was used to explore the driving forces of GGP's influence on conversion of cultivated land to forest land and grassland, comparing and analyzing the results of two rounds of the GGP. The index system and driving factors selected in this paper can more comprehensively reflect the change of land use pattern during implementation of this project, and manifest the contribution of the GGP on land use changes more effectively. Moreover, this study may support regional decision-making on how to rationally run the GGP in the hilly-gully region of the Loess Plateau and improve regional development of land use.

\section{Materials and Methods}

\subsection{Study Area}

The loess hilly-gully region, located in the middle of the Loess Plateau, is the most typical geomorphic type and spatial unit in the Loess Plateau [35]. The loess hilly-gully region covers 14,000,000 ha with the main landforms consisting of ridge-shaped and beamshaped hills. It includes the south part of Inner Mongolia, western Shanxi, northern Shaanxi, southern Ningxia, and central part of Gansu (Figure 1).

The loess hilly-gully region is full of fragmentized terrain and ravines crossbar. Human beings had immoderately reclaimed land and conducted severe deforestation in the region. This kind of behavior resulted in vegetation destruction, soil erosion, and water and soil loss. The loess hilly-gully region belongs to a warm temperate semi-arid continental monsoon climate zone, which results in concentrated precipitation, warm and dry climate, and scarce water resources. The average annual rainfall in the study area is $513.8 \mathrm{~mm}$, and more than $90 \%$ of rainfall is concentrated in May to September. The distribution of surface runoff during the year is concentrated, and the runoff in the flood season (June to September) accounts for more than $70 \%$ of annual runoff, even concentrated in a few heavy rains. Due to the rapid population growth and declining land carrying capacity, the loess hilly-gully region is designated as a key area for the GGP. 

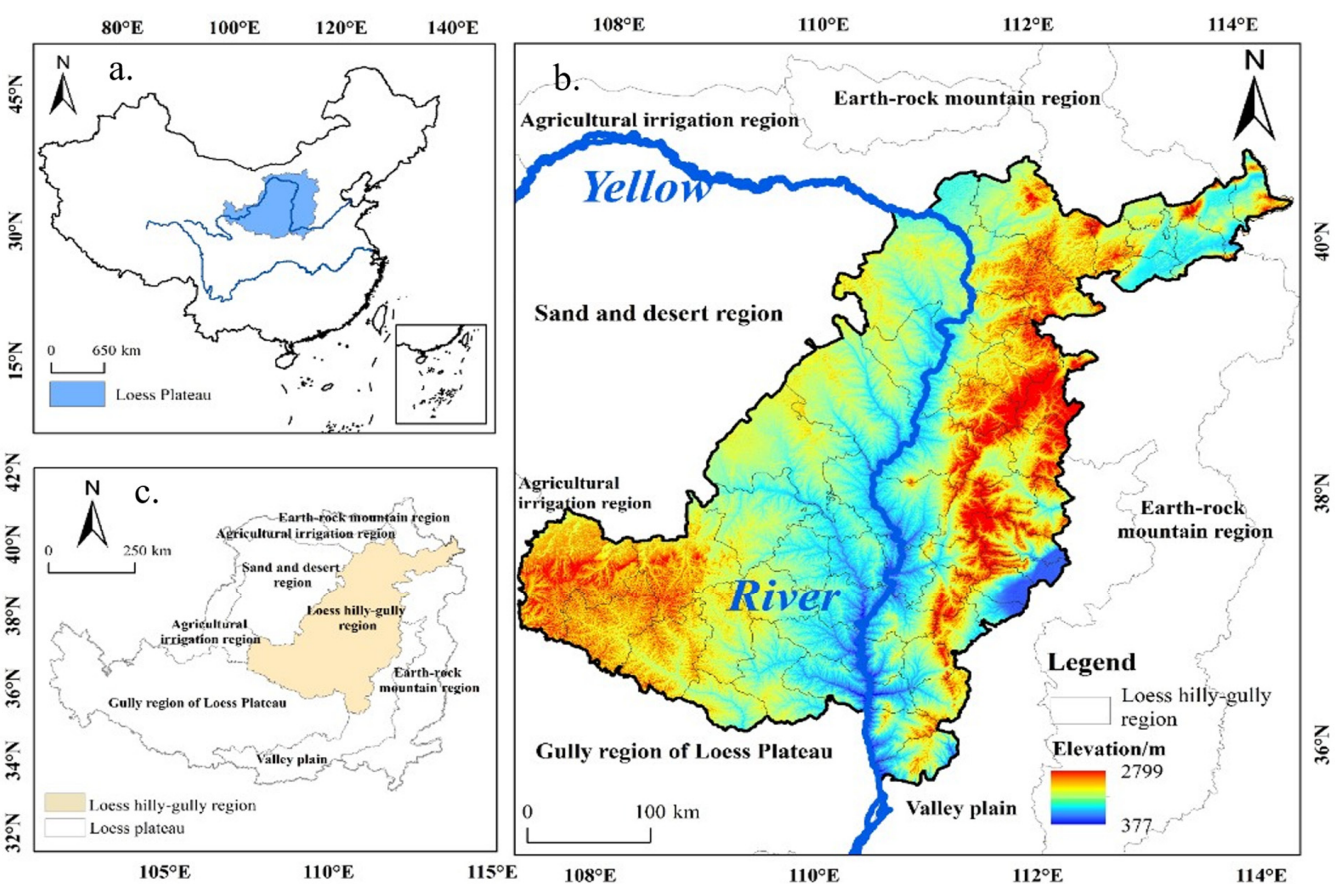

Figure 1. The geographical location of the loess hilly-gully region. All figures represent borders of China (a); location of the loess hilly-gully region (b); different regions of the Loess Plateau (c).

\subsection{Data Sources and Preprocessing}

Landsat TM, ETM+ and OLS remote sensing image datasets utilized in 2000, 2010, and 2018 were all sourced from the Data Center for Resources and Environmental Sciences, Chinese Academy of Sciences (RESDS) (http:/ / www.resdc.cn/, accessed on 29 January 2021). By conducting manual visual interpretation and field verification, the comprehensive, high-precision evaluation on land showed more than 93\% accuracy at the first-level classification of land use types [36-38]. According to the Chinese land resource classification system established by the "National Remote Sensing Survey and Dynamic Research on Resources and Environment" project [39], six first-level types of land use were identified in this region, namely cultivated land, forest land, grassland, water area, construction land, and unused land (Table 1). Figures of these land use types are displayed in Appendix A.

Based on the ArcGIS platform, this study conducted spatial analysis on the three-phase data of land use (2000,2010, and 2018), and divided three phases into two research periods of 2000-2010 and 2010-2018, respectively. The conversion of cultivated land to forest land and grassland in 2010 compared with 2000 was set as 1, the invariant of forest land and grassland was set as 0 , and other data types were set as no-data. Compared with 2010, the conversion of cultivated land to forest and grassland in 2018 was set as 1, the invariant of forest land and grassland was set as 0 , and other data types were set as no-data. Figures of land use changes of two study periods can be seen in Appendix B.

Based on the results of similar research [29-32] and the actual characteristics, data representation and accessibility of the loess hilly-gully region, this paper selected four categories of driving factors including investment of the GGP, nature, social economy, and geographical location (Table 2). The data sources and pretreatment methods of each specific indicator were as follows: 
Table 1. Classification of land use types of the loess hilly-gully region.

\begin{tabular}{|c|c|}
\hline Land Use Type & Specification \\
\hline Cultivated land & $\begin{array}{l}\text { Refers to the land for planting crops, including mature cultivated } \\
\text { land, newly reclaimed wasteland, recreational land, wheel rest, } \\
\text { grassland rotation crops; land for fruit, mulberry, agriculture and } \\
\text { forestry mainly planted with crops; and beach and tidal flats for } \\
\text { more than three years. }\end{array}$ \\
\hline Forest land & $\begin{array}{l}\text { Refers to forest land used for growing trees, shrubs, bamboos, } \\
\text { and coastal mangrove land. Includes natural forest with canopy } \\
\text { closure greater than } 30 \% \text {, shrub wood with canopy closure } \\
\text { greater than } 40 \% \text {, open woodland with canopy closure of } 10-30 \% \text {, } \\
\text { and other forests. }\end{array}$ \\
\hline Grassland & $\begin{array}{c}\text { Refers to all types of grasslands that are dominated by growing } \\
\text { herbaceous plants and have a coverage of more than } 5 \%, \\
\text { including shrub grasses dominated by grazing and sparsely } \\
\text { forested grasslands with a canopy closure below } 10 \% \text {. }\end{array}$ \\
\hline Water area & $\begin{array}{l}\text { Refers to natural or artificial land and land used for water } \\
\text { conservancy facilities, including rivers, lakes, reservoir pits, etc. }\end{array}$ \\
\hline Construction land & $\begin{array}{l}\text { Refers to urban and rural residential areas, industrial and mining, } \\
\text { transportation and other land outside the country, including } \\
\text { urban, rural residential areas, and other construction land. }\end{array}$ \\
\hline Unused land & $\begin{array}{c}\text { Refers to unused land and hard to use land, including bare rocky } \\
\text { gravel and bare land. }\end{array}$ \\
\hline
\end{tabular}

Table 2. List of independent variables used in logistic regression modeling.

\begin{tabular}{|c|c|c|c|}
\hline Variables & Description & Types of Variables & Unit \\
\hline the GGP & $\begin{array}{l}\text { Total Cumulative investment of the } \\
\text { GGP from } 2000 \text { to } 2010 \text { and } 2010 \\
\text { to } 2018\end{array}$ & Continuous variable & ten thousand yuan \\
\hline \multicolumn{4}{|l|}{ Natural variables } \\
\hline Elevation & Digital elevation model (DEM) & Continuous variable & $\mathrm{m}$ \\
\hline Slope & Slope gradient derived from DEM & Dichotomous variable & $\circ$ \\
\hline SOM & Soil Organic Matter & Continuous variable & $\%$ \\
\hline Soil pH & $\mathrm{pH}$ values of soil & Continuous variable & NA \\
\hline Annual mean temperature & $\begin{array}{l}\text { Average mean temperature from } \\
2000 \text { to } 2010 \text { and } 2010 \text { to } 2018\end{array}$ & Continuous variable & ${ }^{\circ} \mathrm{C}$ \\
\hline Annual mean precipitation & $\begin{array}{l}\text { Average mean precipitation from } \\
2000 \text { to } 2010 \text { and } 2010 \text { to } 2018\end{array}$ & Continuous variable & $\mathrm{mm}$ \\
\hline \multicolumn{4}{|l|}{ Socio-economic variables } \\
\hline Population density & $\begin{array}{l}\text { Changes of population density from } \\
2000 \text { to } 2010 \text { and } 2010 \text { to } 2018\end{array}$ & Continuous variable & persons $/ \mathrm{km}^{2}$ \\
\hline Rural population density & $\begin{array}{l}\text { Changes of rural population density } \\
\text { from } 2000 \text { to } 2010 \text { and } 2010 \text { to } 2018\end{array}$ & Continuous variable & persons $/ \mathrm{km}^{2}$ \\
\hline GDP per land area & $\begin{array}{l}\text { Changes of GDP per land area of } \\
2000 \text { to } 2010 \text { and } 2010 \text { to } 2018\end{array}$ & Continuous variable & ten thousand yuan \\
\hline \multicolumn{4}{|l|}{ Geographical variables } \\
\hline Dis_road & $\begin{array}{l}\text { Euclidean distance of each pixel to } \\
\text { the closest major road }\end{array}$ & Continuous variable & $\mathrm{m}$ \\
\hline Dis_river & $\begin{array}{l}\text { Euclidean distance of each pixel to } \\
\text { the closest major river }\end{array}$ & Continuous variable & $\mathrm{m}$ \\
\hline Dis_residential area & $\begin{array}{l}\text { Euclidean distance of each pixel to } \\
\text { the closest residential area }\end{array}$ & Continuous variable & $\mathrm{m}$ \\
\hline Dis_city & $\begin{array}{l}\text { Euclidean distance of each pixel to } \\
\text { the closest city }\end{array}$ & Continuous variable & $\mathrm{m}$ \\
\hline
\end{tabular}




\subsubsection{Natural Data}

This data mainly included two topographic factors of elevation and slope, two meteorological factors of annual mean temperature and annual mean precipitation, soil organic matter (SOM), and soil $\mathrm{pH}$. The data of elevation and slope were dated from the Geospatial Data Cloud (http:/ / www.gscloud.cn/, accessed on 29 January 2021). Moreover, according to the grade standard of cultivated land slope stipulated in the third national land survey technical regulation (TD/T 1055-2019), this study divided the slope of the study area into five grade classes, namely $<2^{\circ}, 2 \sim 6^{\circ}, 6 \sim 15^{\circ}, 15 \sim 25^{\circ}$, and $>25^{\circ}$, and regarded the land with a slope $<2^{\circ}$ as flat land. The data of meteorological factors originated from the annual data set of Chinese surface climate data provided by the China Meteorological Science Data Service Center (https: / / data.cma.cn/, accessed on 29 January 2021). The annual mean precipitation and temperature in two study periods (2000-2010 and 2010-2018) were calculated according to the annual climate data of 49 meteorological stations in the loess hilly-gully region and nearby areas from 2000 to 2018. In addition, this study used ArcGIS 10.3 software to implement the spatial simulation of meteorological factors based on the inverse distance weight interpolation. Furthermore, the data of soil $\mathrm{pH}$ and total organic carbon (TOC) $(2009,1 \mathrm{~km} \times 1 \mathrm{~km})$ derived from the Harmonized World Soil Database (http:/ / www.fao.org/soils-portal/soil-survey/soil-maps-and-databases / harmonized-world-soil-database-v12/en/, accessed on 29 January 2021), and the value of soil organic matter (SOM) was calculated based on the data of total organic carbon (TOC).

\subsubsection{Socio-Economic Data and Investment of the GGP}

The socio-economic data mainly includes total population density, rural population density, and GDP per land area from 2000 to 2018. The data of total population, rural population, and GDP per land area of every county in the loess hilly-gully region came from the statistical yearbook of Shanxi, Inner Mongolia, and Shaanxi. The data of cumulative investment of the GGP came from national park administration of national forestry and grassland administration (http:/ / www.forestry.gov.cn/, accessed on 29 January 2021). The socio-economic data and investment of the GGP of each county were collected by Excel and spatialized by ArcGIS 10.3 software.

\subsubsection{Geographical Data}

It mainly includes the distance to the nearest road, the distance to the nearest city, the distance to the nearest residential area, and the distance to the nearest river. Among them, the data on road and river came from the 1:1 million national basic geographic database published by the National Basic Geographic Information Center (http:/ / www.webmap. com, accessed on 29 January 2021). Data on residential area and city are extracted from land use data in the loess hilly-gully region of 2018. The spatial distance calculation of each factor was completed by using the Euclidean distance tool in ArcGIS 10.3 software.

The scope of the hilly-gully region of the Loess Plateau originates from the "Comprehensive Management Planning Outline of the Loess Plateau region (2010-2030)" issued by China. Vector data about 62 administrative districts came from the national 1:1,000,000 database of the National Fundamental Geographic Information System (http: / / www.webmap.com, accessed on 29 January 2021). The spatial resolution of data was resampled to $90 \mathrm{~m} \times 90 \mathrm{~m}$, and uniformly converted to Krasovsky_1940_albers projection to ensure the consistency of all data in space. All visualized driving factors of conversion of cultivated land to forest land and grassland are shown in Appendix C.

\subsection{Analytic Tools and Equations}

\subsubsection{Spatial Calculating Analysis Model}

This study focused on characterizing quantity, direction, and spatial form of the conversion of cultivated land to forest land and grassland in the loess hilly-gully region from 2000 to 2010 and 2010 to 2018. To achieve this, dynamic indexes were used to describe change range and speed of the conversion of cultivated land to forest land and grassland. 
In addition, this study analyzed the conversion with the transition matrix to reveal the law and characteristics of this type of land use change in the study area.

Single land use dynamic degree:

The dynamic degree of land use reflects the quantity change of land use types in a certain period of time [40]. The single dynamic degree of land use refers to the change of a certain land type in the study area in a certain period of time, which is used to represent the change speed and range of a certain land use type in a certain period [40]. The formula is as follows:

$$
K=\frac{\left(U_{b}-U_{a}\right)}{U_{a}} \times \frac{1}{T} \times 100 \%
$$

where $K$ is the dynamic degree of a certain land use type during the study period; $U_{a}$ and $U_{b}$ are area of a certain land use type during the initial period of the study and the end of the study, respectively; $T$ is the study duration, when time period of $T$ is set to years at time, the value of $K$ is annual rate of change of a certain land use type in the study area. Based on analysis of the land use transition matrix, this study analyzed the conversion of cultivated land to forest land and grassland during 2000 to 2010 and 2010 to 2018 to show the dynamic change of cultivated land to forest land and grassland more intuitively.

Land use transition matrix:

The land use transition matrix reflects dynamic process of the mutual transformation between all kinds of land-use types at the beginning and the end of a certain period in a certain region [41]. It can specifically reflect the structural characteristics of land use change and the direction of conversion among various types [42]. This study conducted statistical analysis of two-phase data of land use change with overlay analysis function in the ArcGIS software, and obtained the land use conversion relationship matrix of the loess hilly-gully region during two study intervals of 2000-2010 and 2010-2018. The formulas are as follows:

$$
D_{i j}=\sum_{i j}^{n}\left[\frac{S_{i-j}}{S_{i}}\right] \times 100 \%
$$

where $D_{i j}$ is the ratio of conversion from land-use type $i$ to $j$ in the research period; $S_{i}$ is the initial area of land-use type $i$ in the study area; $S_{i-j}$ is the conversion area from land-use type $i$ to land-use type $j$ during the study period; $n$ is the quantity of land-use types transformed in the study area.

A land-use conversion matrix is generated to capture the multidirectional change among types of LUCC; the formula is as follow:

$$
S_{i j}=\left[\begin{array}{cccc}
S_{11} & S_{12} & \cdots & S_{1 j} \\
S_{21} & S_{22} & \cdots & S_{2 j} \\
\vdots & \vdots & \cdots & \vdots \\
S_{i 1} & S_{i 2} & \cdots & S_{i j}
\end{array}\right]
$$

where $S$ represents the area; $n$ represents the quantity of land use types before and after the transformation; $i, j(i, j=1,2, \ldots, n)$ represent land use types before and after the transformation, respectively; $S_{i j}$ represents the area that the land type $i$ transfer to the land type $j$. Each row element in the matrix represents flow information of the $i$ land category before the transfer to each category after the transfer, and each column element in the matrix represents the source information of the $j$ land category area after the transfer from each category before the transfer. The number of land use types before and after the transfer can be different. At this time, the number of rows and columns of $S_{i j}$ is different, which is a general matrix. For research convenience, the same classification system and classification accuracy are usually used before and after the transfer, so that the number of rows and columns of $S_{i j}$ is the same, and it is an n-order square matrix. 


\subsubsection{Logistic Regression Model}

The binary logistic regression (BLR) model can be applied in the analysis of twocategory dependent variable, which can be used to analyze the relationship between probability of land use change and socio-economic factors, natural factors, and geographical factors effectively $[43,44]$. In this paper, the conversion between cultivated land and forest land and grassland $(\mathrm{Y})$ is a dichotomous variable, that is, when cultivated land is converted to forest land and grassland, $Y=1$, and, when forest land and grassland remains unchanged, it is 0 . Based on the sampling data, regression coefficients are generated for the respective variables. These coefficients can be used to explore the relationship between dependent and independent variables in the model. $P$ is set to the probability of event occurrence, and the value range is $0 \sim 1$, then 1-P is the probability that the event will not occur. We built the binary logistic regression model to identify the relationship between multiple variables of driving forces and the LUCC [43]. This probability can be calculated by logistic function, the formula is as follows:

$$
P=\left(Y=1 \mid x_{1}, x_{2}, \ldots, x_{n}\right)=\frac{\exp \left(\beta_{0}+\sum \beta_{i} x_{i}\right)}{\left(1+\exp \left(\beta_{0}+\sum \beta_{i} x_{i}\right)\right)}
$$

Equation (4) is usually transformed into a linear equation (5) by logistic transformation:

$$
\log \left(\frac{P_{i}}{1-P_{i}}\right)=\beta_{0}+\beta_{1} x_{1 i}+\beta_{2} x_{2 i} \ldots+\beta_{n} x_{n i}
$$

where $P_{i}$ represents the probability that a certain land use type $i$ may appear in each grid unit; $x_{i}$ represents the impact factor; $\beta$ coefficient is the relationship coefficient diagnosed by the Logistic regression equation, where $\beta_{0}$ is a constant, $\beta_{1} \sim \beta_{n}$ represent the impact factors, respectively. The correlation between $x_{1 i} \sim x_{n i}$ and land use type $i$, the greater the value of $\beta$, the higher the correlation is. $\exp \beta$ represents odds ratio of the event, and represents change in the occurrence rate of land type for each additional unit of the independent variable (impact factor). $\exp \beta<1$, the incidence rate decreases; $\exp \beta=1$, the incidence rate remains unchanged; $\exp \beta>1$, the incidence rate increases. $\frac{P_{i}}{1-P_{i}}$ is referred to as the odds ratio and $\log \left(\frac{P_{i}}{1-P_{i}}\right)$ is the logs of the odds ratios or "logit".

Wald $\chi^{2}$ is significance test statistic of the regression coefficient, which is used to evaluate the degree of explanation of each independent variable to the dependent variable [45]. This study used Wald $\chi^{2}$ statistic to test regression coefficients of the model. The significance level is 0.05 , if the significance value corresponding to the Wald $\chi^{2}$ statistic of the independent variable $>0$, it is considered that the regression coefficient of the independent variable is not significantly different from null hypothesis and should be removed; otherwise, it is retained [45]. The likelihood ratio chi-square test is performed on the regression equation, and when the value of probability $\mathrm{P}$ is less than the given significance level, it indicates that parameter estimation is effective, and the model can be used. In addition, the modeling results should also be evaluated [43]. The ROC curve is often used to measure goodness of the logistic regression model [46]. The value of the area under ROC curve is between 0.5 and 1.0. The higher the value, the better the goodness of the logistic regression analysis model is, and vice versa. The ROC value of a completely random model is 0.5 , if it is completely correlated, the value is 1.0. The analysis indicates that the model has a relatively high level of good explanatory ability with the ROC above 0.5 [46].

\subsection{Sampling Process}

To ensure a sufficient number of samples and avoid spatial autocorrelation of data since results of logistic regression model are closely related to sample selection [43,44], this paper used stratified random sampling to extract a total of 6000 samples evenly distributed throughout the study area for two study periods of 2000-2010 and 2010-2018, respectively. These samples included 2000 points of unchanged forest land and 2000 points of unchanged grassland, 1000 points of conversion of cultivated land to forest land, and 1000 points of 
conversion of cultivated land to grassland. In the ArcGIS platform, the vector point layer was established by using the sampling point, and the vector point was used to extract the value of dependent variables and independent variable, respectively. Finally, attributes obtained from the sampling point were merged to provide basic data for the logistic regression model.

\section{Results}

\subsection{Land Use Change in the Loess Hilly-Gully Region}

\subsubsection{The Characteristics and Topographic Factor of LUCC}

In 2000, 2010, and 2018, the area of cultivated land accounted for $36.94 \%, 33.85 \%$, and $33.69 \%$ of the total area; the area of forest land occupied $16.51 \%, 17.76 \%$, and $17.63 \%$ of the total area; and grassland made up $40.2 \%, 41.58 \%$, and $40.83 \%$ of the total area, respectively. These three land types reached up to $93.65 \%, 93.2 \%$, and $92.15 \%$ of the total area in 2000 , 2010, and 2018, respectively. However, the remaining land use types including water area, construction land and unused land occupied only $6.35 \%, 6.8 \%$, and $7.85 \%$ of this region, respectively. In terms of spatio-temporal characteristics of land use change, the areas for conversion of cultivated land to forest land and grassland in 2000-2010 and 2010-2018 were mainly located in the north part and southwest of the study area.

Based on the slope classification above, this paper utilized the area tabulation tool in ArcGIS software to conduct spatial superposition calculation of the slope classification maps and the land use spatial transfer maps including two phases of 2000-2010 and 2010-2018, and obtained the conversion area of cultivated land to forest land and grassland in the range of different grades of slope of two study periods (2000-2010 and 2010-2018). Moreover, excel software was used for conducting statistics and making figures, which illustrated that the outward-transferring areas of cultivated land to forest land and grassland were different based on the changes of slope in the loess hilly-gully region. Conversion of cultivated land to forest land and grassland represented upward and then a downward trend from 2000 to 2010 and 2010 to 2018. The largest area transferred from cultivated land to forest land and grassland within the slope range of $6-15^{\circ}$. The area of $102,041.37 \mathrm{ha}$ and $55,814.67$ ha from 2000 to 2010, and the area of 368,211.42 ha and 321,989.58 ha from 2010 to 2018 were converted to forest land and grassland, accounting for $44.61 \%$ and $50.85 \%$, and $51.05 \%$ and $52.57 \%$ of the total converted cultivated land in different slope grades, respectively. The results revealed that the GGP was implemented vigorously on the slope range of $6-15^{\circ}$ in the loess hilly-gully region.

\subsubsection{Land Use Change Magnitude and Dynamic Degree}

The results of change magnitude and dynamic degree of LUCC in the loess hilly-gully region from 2000 to 2010 and 2010 to 2018 were presented in Table 3.

Table 3. Quantitative changes of land use in the loess hilly-gully region of 2000-2010 and 2010-2018.

\begin{tabular}{|c|c|c|c|c|c|c|c|}
\hline & & Cultivated Land & Forest Land & Grassland & Water Area & Construction Land & Unused Land \\
\hline \multicolumn{8}{|c|}{ Magnitude of LULC Change } \\
\hline Decreased & $2000-2010$ & $106,5131.37$ & $212,411.16$ & $730,227.96$ & 38,277 & 25,077 & 109,096 \\
\hline part $/ \mathrm{hm}^{2}$ & 2010-2018 & $825,070.05$ & $259,053.39$ & $887,063.4$ & $26,116.02$ & $40,619.88$ & $78,554.61$ \\
\hline Increased & $2000-2010$ & 784,662 & $386,031.42$ & $922,339.71$ & $25,730.46$ & 161,757 & $47,998.98$ \\
\hline part $/ \mathrm{hm}^{2}$ & 2010-2018 & $802,691.37$ & $240,603.21$ & $780,929.1$ & $32,488.29$ & $204,238.26$ & $55,527.12$ \\
\hline Annual change & $2000-2010$ & $-0.91 \%$ & $0.70 \%$ & $0.33 \%$ & $-0.89 \%$ & $4.75 \%$ & $-1.19 \%$ \\
\hline rate $(\%)$ & 2010-2018 & $-0.05 \%$ & $-0.08 \%$ & $-0.19 \%$ & $0.40 \%$ & $3.61 \%$ & $-0.46 \%$ \\
\hline \multicolumn{8}{|c|}{ LULC total area $/ \mathrm{hm}^{2}$} \\
\hline 200 & & $5,150,440.08$ & $2,303,072.19$ & $5,607,520.65$ & $152,960.4$ & $152,210.34$ & $579,840.93$ \\
\hline 201 & & $4,720,761.81$ & $2,477,076.39$ & $5,799,495.51$ & $140,445.9$ & $289,720.8$ & $518,361.93$ \\
\hline 201 & & $4,697,968$ & $2,457,994$ & $5,693,177$ & 146,266 & 453,314 & $495,476.19$ \\
\hline
\end{tabular}


During the study period of 2000-2010, Table 3 indicated that forest land, grassland, and water area represented rising tendencies while the area of cultivated land, construction land, and unused land decreased from 2000 to 2010. Specifically, the total area of cultivated land reduced from 5,150,440 ha in 2000 to 4,720,762 ha in 2010; the decreased part of cultivated land was $429,678 \mathrm{ha}$, and the annual change rate of cultivated land was $0.91 \%$ in 10 years. The area of cultivated land maintained an outward-transferring trend, and net loss of cultivated land made up $9.1 \%$ of the total cultivated land in 2010. As for forest land and grassland, the area grew from 2,303,072 ha and 5,607,521 ha in 2000 to 2,477,076 ha and 5,799,496 ha in 2010, respectively. The incremental portions were 174,004 ha and $191,975 \mathrm{ha}$, and annual change rates of forest land and grassland were $0.70 \%$ and $0.344 \%$, respectively. The net increases in forest land and grassland were 174,004 ha and 191,975 ha respectively, accounting for $7.02 \%$ and $3.31 \%$ of the total forest land and grassland in 2010, respectively. In addition, water area and unused land represented downward trends while the construction land increased significantly. The area of water area and unused land reduced from 152,960 ha and 579,841 ha in 2000 to 140,446 ha and 518,362 ha in 2010, net loss of these two types of land use were 125,145 ha and 61,479 ha, and the annual change rates were $-0.89 \%$ and $-1.19 \%$, respectively. In contrast, construction land increased from 152,211 ha in 2000 to $289,720.8$ ha in 2010 ; the annual change rate was $2.56 \%$.

During the study period of 2010 to 2018, the results revealed that the area of cultivated land, forest land, grassland, and unused land all showed declining trends whereas water area and construction land increased. Specifically, the total area of cultivated land reduced from 4,720,762 ha in 2010 to 4,697,968 ha in 2018. The decreased part was 22,793 ha, the annual change rate of cultivated land was $-0.06 \%$ within eight years. The area of forest land and grassland dropped dramatically from 2,477,076 ha and 5,799,496 ha to 2,457,994 ha and 5,693,177 ha, respectively. The reduced portions were 19,082 ha and 106,318 ha, and the annual change rates of forest land and grassland were $-0.1 \%$ and $-0.23 \%$, respectively. The decreased parts accounted for $0.49 \%$ of total cultivated land, $0.78 \%$ of the forest, and $1.51 \%$ of grassland in 2018, respectively. Above all, areas of cultivated land, forest land, and grassland maintained outward-transferring trends in eight years. Furthermore, the area of water area and construction land increased from 140,446 ha and 289,721 ha in 2010 to 146,266 ha and 453,314 ha in 2018 ; the growing parts occupied $3.98 \%$ and $36.09 \%$ of the total water area and construction land in 2018, respectively. In contrast, unused land dropped from 1,692,429 ha in 201 to 3,219,077 ha in 2018; the decreased part was 22,886 ha, making up $4.62 \%$ of the area of unused land in 2018.

\subsubsection{The Land Use Conversion Matrix}

Figure 2 shows the trajectories of land-use change in the loess hilly-gully region from 2000 to 2010. The three most important types of land-use change in the loess hilly-gully region were cultivated land, forest land, and grassland. Cultivated land underwent the greatest change among all categories of LUCC by mainly converting 1,065,131 ha area to other types of land use in 10 years. The biggest area of 724,370 ha was converted to grassland, accounting for $68.01 \%$ of the total outward-transferring area of cultivated land. Grassland was the land type with the maximum inward-transferring area under the influence of the biggest conversion area from cultivated land, which made up $78.54 \%$ of the total area that converted to grassland. Besides, the area of forest transferred to grassland accounted for $10.79 \%$ of the total area that transferred to grassland. The grassland was mainly converted into cultivated land and forest, the converted areas were 493,169 ha and 149,155 ha in 10 years, accounting for $67.54 \%$ and $20.43 \%$ of the total outward-transferring area of grassland, respectively. Grassland was also the land type with the most area that converted to the forest and cultivated land. The area transferred from grassland to cultivated land and forest land accounted for $77.59 \%$ and $38.64 \%$ of the region that converted to cultivated land and forest land, respectively. As for construction land, water area and unused land, both water area and construction land transferred the most area into cultivated land, transferred parts made up $44.77 \%$ and $58.4 \%$ of the total outward- 
transferring area of water area and construction land, respectively, and $73.82 \%$ of unused land transferred into grassland.

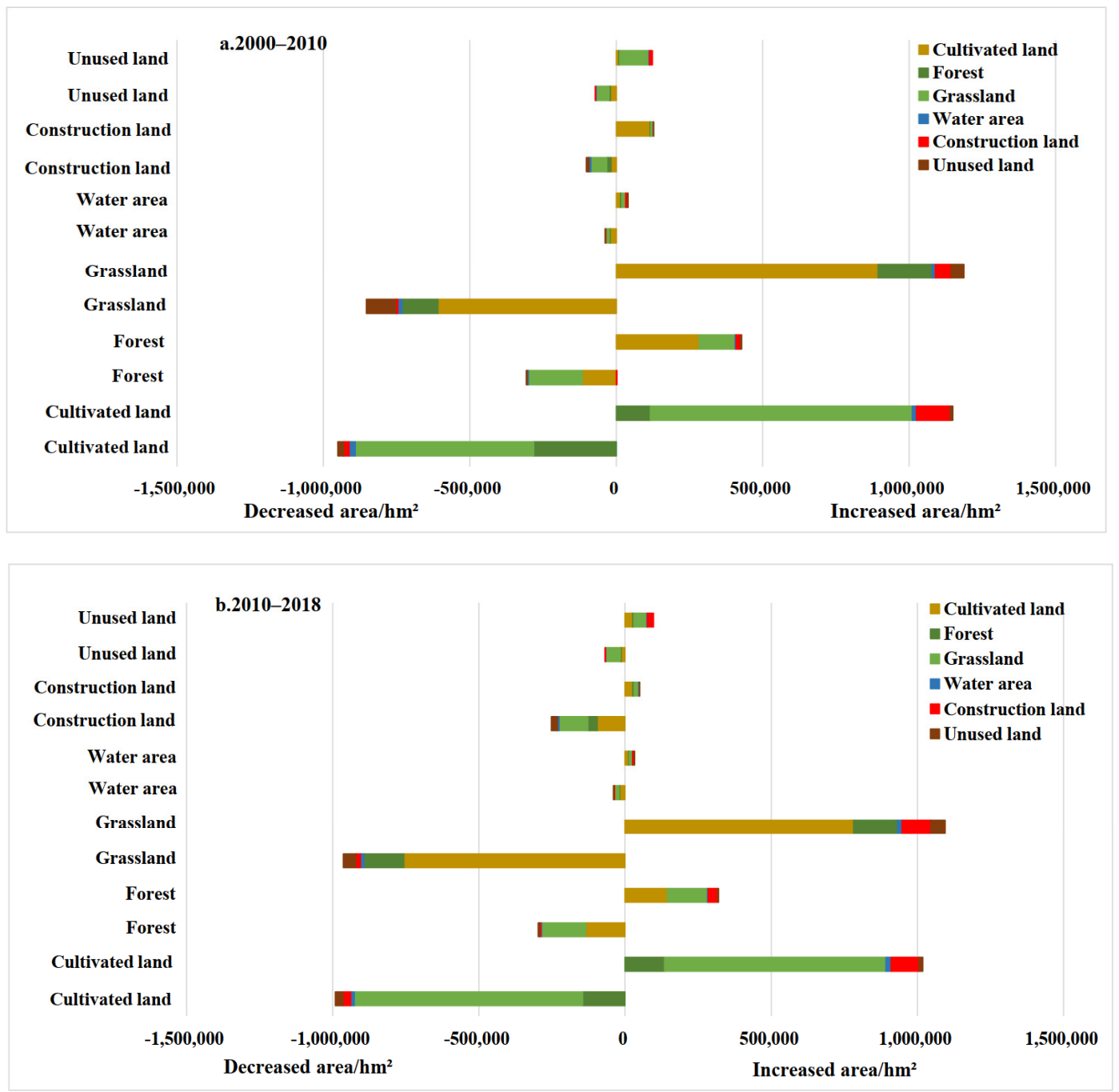

Figure 2. Trajectories of land use changes in the loess hilly-gully region from 2000 to2010 (a) and 2010 to 2018 (b).

Figure 2 shows the directions of land use change in the loess hilly-gully region from 2010 to 2018. The main types of land use change in the loess hilly-gully region were cultivated land, forest land, and grassland. Among them, cultivated land was the land with the most land conversion, which mainly transferred an area of 722,434 ha into forest land and grassland. 613,038 ha of cultivated land was converted into grassland in eight years, accounting for $84.86 \%$ of the outward-transferring area of cultivated land, which also occupied $78.5 \%$ of the inward-transferring area of grassland. Moreover, grassland converted the most area to cultivated land and forest land. Cultivated land and forest obtained the greatest conversion area from grassland, making up $76.37 \%$ and $46.08 \%$ of the total inward-transferring area, respectively. Furthermore, 109,396 ha of cultivated land was converted to forest land in eight years, accounting for $13.26 \%$ of the outward-transferring area of cultivated land. The area of forest was mainly converted to cultivated land and grassland, conversion areas were 117,275 ha and 110,859 ha, accounting for $45.27 \%$ and $42.79 \%$ of outward-transferring areas of forest, respectively. As for water area, construction land and unused land, both water area and construction land transferred the most area into cultivated land; the transferred parts made up $37.56 \%$ and $52.40 \%$ of the total outwardtransferring area of construction land and water area, respectively. $44.72 \%$ of unused land transferred into grassland. 
During two study periods of 2000-2010 and 2010-2018, the greatest change among land use types was the conversion of cultivated land to forest land and grassland. The GGP changed the structure and pattern of regional land use, which in turn changed the local land cover status; additionally, green vegetation coverage has been increased significantly in the loess hilly-gully region.

\subsection{Results of the BLR Models}

This study conducted the multi-collinearity diagnostic analysis for respective variables before constructing a logistic regression model of driving factors that influenced the conversion from cultivated land to forest land and grassland. Tolerances of independent variables were between 0.5 0.95 and Variance Inflation Factor (VIF) was less than 10, which shows that collinearity between the independent variables was not serious and they can all be included in the logistic regression model.

In the regression model of the conversion of cultivated land to forest land and grassland, four dummy variables were employed to represent slope grade II $\left(2-6^{\circ}\right)$ and slope grade III $\left(6-15^{\circ}\right)$, slope grade IV $\left(15-25^{\circ}\right)$, slope grade $\mathrm{V}\left(>25^{\circ}\right)$, and the referent was slope grade $\mathrm{I}\left(<2^{\circ}\right)$.

\subsubsection{Results of the BLR Model from 2000 to 2010}

Table 4 demonstrated the results of the logistic regression model for the conversion of cultivated land to forest land and grassland from 2000 to 2010 . The observed value of likelihood ratio chi-square test was $667.755(p=0.000)$, which demonstrated that building the whole regression model was of great significance. Besides, the value of the area under the ROC curve (AUC) was greater than 0.7 , indicating that the chosen variables can adequately explain the conversion from cultivated land to forest land and grassland. According to the value of Wald $\chi^{2}$, elevation, investment of the GGP, annual mean temperature, slope III $\left(6-15^{\circ}\right)$, GDP per land area, soil $\mathrm{pH}$, distance to river, distance to residential, distance to city and rural population density were the 10 most important spatial determinants of the conversion of cultivated land to forest land and grassland from 2000 to 2010.

Table 4. Driving factors analysis of conversion of cultivated land to forest and grassland in the loess hilly-gully region from 2000 to 2010.

\begin{tabular}{|c|c|c|c|c|c|}
\hline Driving Factors & $\begin{array}{c}\text { Parameter } \\
\text { Estimation }(\beta)\end{array}$ & Standard Error (S.E) & $\begin{array}{c}\text { Test Statistic } \\
\text { Wald } \chi 2\end{array}$ & Significance $(p)$ & $\begin{array}{c}\text { Odds Ratio } \\
\exp (\beta)\end{array}$ \\
\hline Constant & 2.358 & 0.703 & 11.245 & $0.001^{* * *}$ & 10.565 \\
\hline the GGP & 0.000 & 0.000 & 149.330 & $0.000^{* * *}$ & 1.000 \\
\hline Elevation & -0.002 & 0.000 & 181.567 & $0.000 * * *$ & 0.998 \\
\hline Slope & - & - & 42.862 & 0.000 & - \\
\hline Slope II $\left(2-6^{\circ}\right)$ & 0.784 & 0.324 & 5.870 & $0.015^{* *}$ & 2.190 \\
\hline Slope III $\left(6-15^{\circ}\right)$ & 1.297 & 0.314 & 17.115 & $0.000^{* * *}$ & 3.659 \\
\hline Slope IV (15-25) & 1.061 & 0.307 & 11.947 & $0.001^{* * *}$ & 2.889 \\
\hline Slope V $\left(>25^{\circ}\right)$ & 0.821 & 0.310 & 7.025 & $0.008^{* * *}$ & 2.274 \\
\hline SOM & -0.049 & 0.068 & 0.514 & 0.473 & 0.952 \\
\hline Soil pH & 0.216 & 0.047 & 21.378 & $0.000^{* * *}$ & 1.241 \\
\hline $\begin{array}{l}\text { Annual mean } \\
\text { temperature }\end{array}$ & -0.407 & 0.038 & 114.379 & $0.000^{* * *}$ & 0.666 \\
\hline $\begin{array}{l}\text { Annual mean } \\
\text { precipitation }\end{array}$ & 0.002 & 0.001 & 5.235 & $0.022^{* *}$ & 1.002 \\
\hline Pop_density & 0.004 & 0.002 & 3.514 & 0.061 & 1.004 \\
\hline Rural pop_density & 0.012 & 0.005 & 5.703 & $0.017^{* *}$ & 1.012 \\
\hline GDP per land area & 0.000 & 0.000 & 36.456 & $0.000^{* * *}$ & 1.000 \\
\hline DIS_road & 0.000 & 0.000 & 0.119 & 0.730 & 1.000 \\
\hline DIS_river & 0.000 & 0.000 & 14.401 & $0.000^{* * *}$ & 1.000 \\
\hline $\begin{array}{c}\text { DIS_residential } \\
\text { area }\end{array}$ & 0.000 & 0.000 & 13.961 & $0.000^{* * *}$ & 1.000 \\
\hline DIS_city & 0.000 & 0.000 & 8.611 & $0.003^{* * *}$ & 1.000 \\
\hline
\end{tabular}


The significance level of regression coefficient $(p<0.05)$ and statistics illustrated that elevation was the most vital explanatory variable. The regression coefficient of elevation was -0.00194 and the odds ratio was 0.9981 , indicating that the probability of conversion of cultivated land to forest land and grassland decreased by nearly one time with an increase in elevation by 1 degree. Therefore, cultivated land with a lower elevation was more easily transferred to forest land and grassland. The positive coefficients of the GGP's investment, slope III $\left(6-15^{\circ}\right)$, soil $\mathrm{Ph}$, and rural population density led to the increase in the probability of conversion of cultivated land to forest land and grassland with the growth of these independent variables. For every growth in the GGP's investment, the probability of conversion to forest land and grassland rose by nearly one time. The significance level of slope III $\left(6-15^{\circ}\right)$ was $0.00054<0.05$, the occurrence rate was 2.889 , illustrating that the probability of conversion to forest land and grassland was $88.9 \%$ higher at the slope range of $6-15^{\circ}$ than the reference level of slope grade $\mathrm{I}\left(<2^{\circ}\right)$ in the first stage. In addition, the odds of forest land and grassland expansion increased by $24.1 \%$ for every unit increase in soil pH; with an increase in rural population density, the likelihood of cultivated land converted to forest land and grassland increased by 1.0122 times.

In contrast, annual mean temperature, GDP per land area, distance to river, distance to residential area, and distance to town had negative influences on the conversion of cultivated land to forest land and grassland from 2000 to 2010. To be more specific, for every $1 \%$ increase in annual mean temperature, the occurrence ratio of the conversion of cultivated land to forest land and grassland decreased by roughly $50.24 \%$; for every $1 \%$ increase in GDP per land area, the probability of conversion from cultivated land to forest land and grassland dropped to approximately one time. As for geographical factors, the probabilities of the forest land and grassland expansion increased by nearly one time for every meter decreased in distance to river, to residential area, and to town. In summary, natural factors, the GGP, and socio-economic factors deeply influenced the conversion from cultivated land to forest land and grassland.

\subsubsection{Results of the BLR Model from 2010 to 2018}

Table 5 demonstrated the results of the logistic regression model for the conversion of cultivated land to forest land and grassland from 2010 to 2018. The observed value of likelihood ratio chi-square test was $428.682(p=0.000)$, which demonstrated that building the whole regression model was of great significance. Besides, the value of the area under the ROC curve (AUC) was greater than 0.7, indicating that the chosen variables can adequately explain the conversion from cultivated land to forest land and grassland. According to the value of Wald $\chi^{2}$ and significance level of regression coefficient $(p<0.05)$, investment of the GGP, elevation, rural population density, slope III $\left(6-15^{\circ}\right)$, soil $\mathrm{pH}$, GDP per land area, annual mean precipitation, and distance to road were the eight most important spatial determinants of the conversion of cultivated land to forest land and grassland from 2010 to 2018.

Investment of the GGP, slope III $\left(6-15^{\circ}\right)$, soil $\mathrm{pH}$, annual mean precipitation, and GDP per land area all showed positive influences towards the conversion of cultivated land to forest land and grassland. Specifically, the probability of the conversion from cultivated land to forest land and grassland increased with the growth of the GGP's investment. For every capital increase in investment, the probability of conversion to forest land and grassland rose by one time. The area of cultivated land was $59.15 \%$ more likely to convert to forest land and grassland on the slope grade III $\left(6-15^{\circ}\right)$ compared with reference level of slope grade $\mathrm{I}\left(<2^{\circ}\right)$. Moreover, the probability of conversion to forest land and grassland rose with the increase in soil $\mathrm{pH}$, annual mean precipitation, and GDP per land area. For every $1 \%$ increase in soil $\mathrm{pH}$ and annual mean precipitation, the odds ratios of forest land and grassland expansion grew by 1.2102 times and 1.0036 times, respectively. Besides, the probability of conversion from cultivated land to forest land and grassland would be increased to approximately one time with every 1\% increase in GDP per land area. 
Table 5. Driving factors analysis of the conversion of cultivated land to forest and grassland in the loess hilly-gully region in 2010-2018.

\begin{tabular}{|c|c|c|c|c|c|}
\hline Driving Factors & $\begin{array}{c}\text { Parameter } \\
\text { Estimation }(\beta)\end{array}$ & Standard Error(S.E) & $\begin{array}{l}\text { Test Statistic } \\
\text { Wald } \chi 2\end{array}$ & Significance $(p)$ & $\begin{array}{c}\text { Odds Ratio } \\
\exp (\beta)\end{array}$ \\
\hline Constant & -2.073 & 0.648 & 10.224 & $0.001^{* * *}$ & 0.126 \\
\hline the GGP & 0.000 & 0.000 & 113.083 & $0.000^{* * *}$ & 1.000 \\
\hline Elevation & -0.001 & 0.000 & 96.363 & $0.000^{* * *}$ & 0.999 \\
\hline Slope & & & 28.763 & 0.000 & \\
\hline Slope II $\left(2-6^{\circ}\right)$ & -0.035 & 0.140 & 0.064 & 0.801 & 0.965 \\
\hline Slope III $\left(6-15^{\circ}\right)$ & 0.465 & 0.141 & 10.842 & $0.001^{* * *}$ & 1.591 \\
\hline Slope IV (15-25) & 0.531 & 0.182 & 8.480 & $0.004^{* * *}$ & 1.700 \\
\hline Slope V $\left(>25^{\circ}\right)$ & 0.512 & 0.352 & 2.110 & 0.146 & 1.668 \\
\hline SOM & 0.062 & 0.064 & 0.929 & 0.335 & 1.064 \\
\hline Soil pH & 0.191 & 0.049 & 15.255 & $0.000^{* * *}$ & 1.210 \\
\hline $\begin{array}{l}\text { Annual mean } \\
\text { temperature }\end{array}$ & -0.066 & 0.038 & 2.943 & 0.086 & 0.936 \\
\hline $\begin{array}{l}\text { Annual mean } \\
\text { precipitation }\end{array}$ & 0.003 & 0.001 & 10.101 & $0.001^{* * *}$ & 1.003 \\
\hline Pop_density & 0.000 & 0.002 & 0.019 & 0.891 & 1.000 \\
\hline Rural pop_density & -0.020 & 0.002 & 67.531 & $0.000^{* * *}$ & 0.980 \\
\hline GDP per land area & 0.000 & 0.000 & 13.089 & $0.000^{* * *}$ & 1.000 \\
\hline DIS_road & 0.000 & 0.000 & 5.495 & $0.019^{* *}$ & 1.000 \\
\hline DIS_river & 0.000 & 0.000 & 0.342 & 0.559 & 1.000 \\
\hline $\begin{array}{c}\text { DIS_residential } \\
\text { area }\end{array}$ & 0.000 & 0.000 & 7.404 & $0.007^{* *}$ & 1.000 \\
\hline DIS_city & 0.000 & 0.000 & 0.008 & 0.929 & 1.000 \\
\hline
\end{tabular}

Notes: ${ }^{* *}, * * *$ represent significance at $5 \%$ and $1 \%$.

On the contrary, the model predicted inverse relationships between the conversion of cultivated land to forest land and grassland and the independent variables including elevation, rural population density, and distance to roads. To be more specific, every increase in elevation by 1 degree decreased the odds of conversion to forest land and grassland by 0.9987 times; for every $1 \%$ increase in rural population density, the occurrence ratio of the conversion to forest land and grassland decreased by roughly $2 \%$; for every $1 \%$ increase in the distance to road, the probability of conversion to forest land and grassland would be dropped to nearly one time. In summary, the GGP natural, and socio-economic factors influenced the conversion to forest and grassland more deeply compared with geographical factors.

\section{Discussion}

\subsection{The Impact of the Grain for Green Program (GGP) on Land Use Change}

The Grain for Green Program (GGP) is a nationwide ecological project with the largest investment-scale in China [47]. Land use and cover has undergone large-scale and transformative changes under the effective implementation of the project [48,49]. According to the study results, a total of $88.65 \%$ of cultivated land was converted to forest land and grassland, and the area of forest land and grassland occupied $56.72 \%$ and $58.46 \%$ of the total area in 2000 and 2018, respectively. However, land use changes in the two study periods were different. In the first stage of project implementation (2000-2010), the area of cultivated land declined the most, and the outward-transferring area accounted for $22.56 \%$ of the total area of cultivated land in 2010. Among them, the area converted to grassland occupied $68.01 \%$ of the outward-transferring area of cultivated land, and the area converted to forest land accounted for $21.48 \%$ of the outward-transferring area of cultivated land. From 2010 to 2018, the area of cultivated land, forest land, and grassland all declined. Since China only restarted a new round of the Grain for Green Program (GGP) in 2014, the speed of the GGP slowed down in the second study period. However, grassland still obtained the largest area that converted from the cultivated land, accounting for $74.30 \%$ of the outward- 
transferring area of cultivated land, and the area converted to forest land only accounted for $13.26 \%$ of the outward-transferring area of cultivated land. In addition, results of land use changes in two research periods both illustrated that implementation of the GGP has promoted the conversion of cultivated land to forest land and grassland effectively, which was highly consistent with goal of the project and with other studies [22,47]. At the same time, this study found that the area of cultivated land converted to grassland increased steadily while the area converted to forest land showed a downward trend by comparing two study periods, and the total area of cultivated land that converted to grassland was larger than that transferred to forest land, which were as much as three times and six times of the area of reforestation in 2000-2010 and 2010-2018, respectively. The main reason was that the loess hilly-gully region lacked abundant conditions of water and heat, and the climatic vegetation zone was generally more suitable for grassland than forest land [50]. This was also mutually corroborated with the research conclusions obtained by a previous study [51].

The Grain for Green Program (GGP), which is also called the Sloped Land Conversion Program (SLCP), mainly focused on planting trees and converting cropland or bare land on steep slopes to trees and grasslands [52,53]. Therefore, from the perspective of response of the GGP to topographical factors (Figure 3), the largest area of cultivated land converted to forest land and grassland at the slope range of $6-15^{\circ}$ in the loess hilly-gully region during two study periods. Within this slope range, cultivated land converted area of 228,746 ha to forest land, the converted area was as much as five times of that converted to construction land, water area, and unused land; cultivated land converted the area of 724,074 ha to grassland, the converted area was as much as 18 times of that converted to construction land, water area, and unused land. The GGP has increased the area of forest land and grassland in the loess hilly-gully region to a certain extent, and the ecological environment of this area has also been significantly improved [7,54]. However, this result was different from the research conclusions [12,21], and the standard originally formulated for the implementation of the project in China. According to the implementation standards of the GGP, cultivated land with severe soil erosion and desertification on the slope above $25^{\circ}$ are included in the plan of returning cultivated land [12]. In the process of actual implementation of the project, farmers would return cultivated land with a slope range of less than $15^{\circ}$ to plant economic forests such as date trees, apples, and walnuts, and many barren cultivated land and fields were converted into giant cedar and Chinese pine proactively to strive for government subsidies and improve income [20]. Therefore, majority of cultivated land was converted to forest land on the slope range of $6-15^{\circ}$. In addition, compared with the first study period (2000-2010), reduction of cultivated land in the second study period (2010-2018) showed a downward trend, indicating that parts of forest land and grassland were converted to cultivated land to ensure food supply of the loess hilly-gully region, accounting for $71.36 \%$ and $45.27 \%$ of the outward-transferred area of forest land and grassland, respectively.

\subsection{The Impact of the Driving Mechanism on Conversion of Cultivated Land to Forest Land and Grassland}

Based on the results of BLR, this study identified dominant factors affecting the conversion of cultivated land to forest land and grassland in the loess hilly-gully region during the two periods after the implementation of the GGP. Investment of the GGP was an important explanatory variable for the change of cultivated land to forest land and grassland. This paper used the logistic regression model to measure contribution of the investment to regional change of land use to characterize the impact of the GGP on land use change. Investment of the GGP had significant impacts on the conversion of cultivated land to forest land and grassland in both two study periods. That is, as the investment increased, the probability of conversion from cultivated land to forest land and grassland grew. This is mainly related to the better implementation of the GGP in the loess hilly-gully region: Farmers needed to convert the sloping land originally planted with crops to plant trees since they were main bodies of action for the GGP, which played an indispensable role 
in promoting effective implementation of this project. Moreover, the Chinese government introduced an ecological compensation method in which farmers are provided with money, grain subsidies, and seedling fees. By doing so, the lifestyle, income structure, and level of farmers who returned from farming have been changed, and their overall income has been improved as well. This was not only a fundamental guarantee of the interests of farmers who joined the GGP, but also helped increase the trust of farmers in the government and compensation policies. Therefore, farmers in this area were more willing to participate in the GGP actively $[55,56]$. Increase in investment of the GGP will drive the conversion of cultivated land to forest land and grassland.

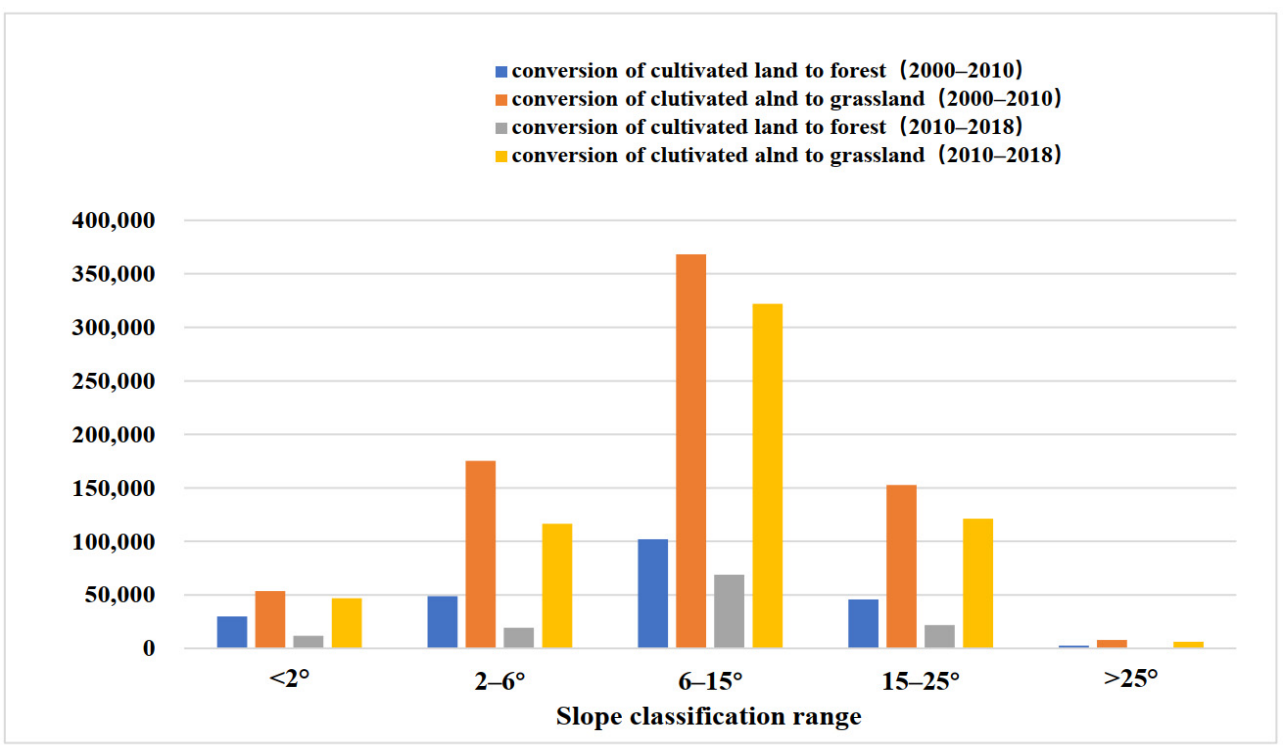

Figure 3. Conversion of cultivated land to forest and grassland at different slope ranges of 2000-2010 and 2010-2018.

In addition, elevation and slope also had significant impacts on the conversion of cultivated land to forest land and grassland. Firstly, as the elevation increased, the logistic model results of the two study periods show that the probability of conversion from cultivated land to forest land and grassland decreased gradually. Specifically, the probability of conversion from cultivated land to forest land and grassland decreased with the increase in elevation. This was related to the fact that the implementation of ecological restoration projects is mostly concentrated in the middle and low elevation areas that are easier to develop at lower costs. The water and heat conditions in this area are relatively abundant, and implementation of the project can increase regional forest land and grassland in a short time. Therefore, it is more effective to achieve the goal of ecological restoration [57]. This conclusion is also consistent with that obtained in these research works [58,59]. In addition, by classifying the slope, this study found that the possibility of converting cultivated land into forest land and grassland at a slope range of $6-15^{\circ}$ is greater than the referents (slope $<2^{\circ}$ ) in the two study periods, and this slope range has the largest contribution; thus, its positive impact on the GGP was also the most significant. This is consistent with the highest conversion area from cultivated land to forest land and grassland in the slope range shown in Figure 3, and with the research conclusion [60]. The reason is that shallow gully erosion on steep farmland in the hilly area of the Loess Plateau is a key factor for serious slope erosion. According to the data on the formation of shallow trenches on sloping cultivated land, the critical slope range of the initial slope of shallow trenches is $15^{\circ}$ to $20^{\circ}$, with an average of $18.2^{\circ}$. Therefore, in order to prevent the formation of shallow gullies, and to alleviate soil erosion more effectively, the critical slope of compulsory ecological conversion of cultivated land in the Loess Plateau is generally controlled within the critical slope of shallow gullies [60]. Therefore, the area with a slope of $6-15^{\circ}$ is the focal area for the GGP 
in the loess hilly-gully region. As for soil $\mathrm{pH}$, the probability of cultivated land being transformed into forest and grassland increased with the increase in soil $\mathrm{pH}$. Since the suitable $\mathrm{pH}$ range mainly affects soil microbial activities, in a neutral to slightly alkaline soil environment, vigorous microbial activities can easily mineralize soil organic matter, which is beneficial for the release of more effective soil nutrients. [61]. Soil $\mathrm{pH}$ in the loess hilly-gully area is weak alkaline, indicating that the soil has sufficient nutrients and is suitable for vegetation growth. Therefore, with increase of the soil $\mathrm{pH}$ value in this area, the possibility of conversion of cultivated land to forest and grassland grew; the annual average temperature also had a negative impact on the conversion of cultivated land to forest and grassland during the period of 2000 to 2010. A moderate increase in temperature is conducive to the growth of vegetation, but too-high temperature will inhibit the expansion of forest and grassland [62]. Therefore, as the temperature rose, the possibility of cultivated land transferring into forest and grassland would decrease.

Apart from above influencing factors, socio-economic and geographical factors were also important factors affecting the Grain for Green Program (GGP) in loess hilly-gully region. The GDP per land area and rural population density selected in this paper had important impacts on the conversion of cultivated land to forest land and grassland. In the first study period (2000-2010), GDP per land area had a negative impact on the increase of forest land and grassland. Continuous acceleration of urbanization driven by economic development leads to a soar in construction land, in addition to phenomena such as arbitrary occupation of cultivated land, forest land, and frequent occurrence of lake reclamation [63]. The contradiction between socio-economic development and ecological construction in the loess hilly-gully region was also more prominent [64]. Therefore, as the GDP per land area increased, the possibility of converting cultivated land into forest land and grassland would decrease. In terms of the increase of grassland, the decline in GDP per land area has led to an increase in the ratio of conversion of cultivated land to grassland. The reason was that farmers in areas with slow economy growth are more inclined to venture out as migrants to improve their incomes. This increases the possibility of farmland degrading into grassland. In addition, the possibility of converting cultivated land into forest land and grassland rises with the increase in rural population density. This is consistent with the conclusion of a previous study [65], since implementation of the GGP can guarantee the income of farmers continuously [66], and farmers in this area have gradually strengthened their environmental awareness and volunteered to participate in ecological restoration projects [67]. Therefore, as the rural population density increases, the probability of converting cultivated land into forest land and grassland will also rise. In the second study period (2010-2018), GDP per land area was positively correlated with the conversion of cultivated land to forest land and grassland, while rural population density was negatively correlated with the change in land use. This is consistent with the findings of existing research conclusions $[68,69]$. With the improvement and depth of the GGP, the project utilizes subsidies, logging restrictions and other methods to influence and change the employment desire of farmers, and promote transfer of labor forces to non-agricultural industries. On one hand, it can promote local socio-economic development and reduce the pressure on land resources caused by growing demands; on the other hand, with the proportion increase of non-agricultural income in the total income of farmers, transfer of non-agricultural labor is also conducive to reducing the phenomenon of imbalance between income and expenditure [70]. Therefore, rural population density decreased (with the GDP per land area increase), and the possibility of cultivated land being converted to forest land and grassland was greater. In addition, geographical factors including the distance to river and the distance to city only have negative impacts on the conversion of cultivated land to forest land and grassland in the first period, while the distance to residential areas has a negative impact on land use changes in both periods. That is, the closer the distance of cultivated land to river, city, and residential areas are, it would be more likely to be converted into forest land and grassland. With rapid development of social economy and urbanization, although the rising demand for expansion of construction land would occupy 
a large area of forest land and grassland [69], under the guidance of a series of ecological protection policies such as ecological civilization construction, the local government is paying more attention to the protection and management of ecological environment, and is pursuing the coordinated development of environment and economy. By planting trees around the city and roads, the coverage of forest land and grassland around city has increased, and the ecological environment has improved [71].

\section{Conclusions}

Using GIS and spatial analysis technology, this paper first analyzed changes of land use in loess hilly-gully region between 2000 to 2010 and 2010 to 2018 from the aspects of quantity and spatio-temporal changes. Secondly, the logistic regression model was established from a natural, socio-economic, geographical aspect and the GGP to explore the driving forces of the conversion of cultivated land to forest and grassland. The main research conclusions are as follows:

Three types of land use including cultivated land, forest land, and grassland changed significantly in the loess hilly-gully region under influence of the GGP from 2000 to 2010 and from 2010 to 2018. Among them, the area of cultivated land was mainly transferred out; increase in the area of forest land and grassland mainly came from the conversion of cultivated land. According to analysis results of land use change, enforcement of the GGP in the first round (2000-2010) and its impact on land use change were greater than that in the second round. In addition, the main method for restoring vegetation coverage is planting grass combined with moderate forest plantation in the loess hilly-gully region.

The main influencing factors of the conversion of cultivated land to forest land and grassland in the two study periods (2000-2010 and 2010-2018) were different, and the contribution degree of different influencing factor was also different. Although investment of the GGP, natural factors, socio-economic factors, and geographical factors were important driving factors in both two study periods, the annual mean temperature, the distance to river, and the distance to city were only more important than natural factor and geographical factor in the first period. In terms of socio-economic factors, from 2000 to 2010, GDP per land area had a greater impact on the conversion of cultivated land to forest land and grassland; while the rural population density played a more vital role in the conversion of cultivated land to forest and grassland in the second period. Comparing the logistic regression model results of the two study periods, we discovered that driving forces in the first period had greater contributions to the conversion of cultivated land to forest land and grassland than that in the second period under impact of the GGP, indicating that scale of implementation was larger and the afforestation effect was better in the period of 2000-2010.

The Chinese government should adjust existing planning guidelines of the GGP, applying the principle of large concentration and small dispersion into implementation of the GGP and determining whether to return cultivated land to forest land or grassland based on types and patterns of land use in different regions, climate, topography, socioeconomic conditions, etc. Furthermore, in order to realize sustainable development of regional land use, the government should also allocate land resources rationally, control the area of returning cultivated land, alleviate the contradiction between humans and land, optimize industrial structure, and raise income of peasant households practically. More importantly, our research results offer a reference to other developing countries on carrying out ecological restoration projects on alleviating soil erosion and sandstorm and improving vegetation coverage.

Author Contributions: Conceptualization, X.Z. and S.Y.; methodology, X.Z.; software, Y.D. and M.H.; validation, S.Y., Y.D. and X.Z.; formal analysis, X.Z.; investigation, X.Z.; resources, Y.D.; data curation, X.Z., Y.D. and M.H.; writing-original draft preparation, X.Z.; writing—review and editing, Y.D. and M.H; visualization, Y.D. and S.Y.; supervision, S.Y.; project administration, X.Z.; funding acquisition, S.Y. All authors have read and agreed to the published version of the manuscript. 
Funding: This research was funded by the Special Fund for Scientific Research of Forestry Commonwealth Industry, grant number 201504424 and National Natural Science Foundation of China, grant number $71473195,71773091$.

Institutional Review Board Statement: Not applicable.

Informed Consent Statement: Not applicable.

Data Availability Statement: Please refer to suggested Data Availability Statements in section “MDPI Research Data Policies" at https:/ / www.mdpi.com/ethics, accessed on 29 January 2021.

Acknowledgments: I am sincerely appreciated for students from the Research Center of Resource Economics and Environmental Management on their contributions to the fund arrangement and calculation of the Grain for Green Project.

Conflicts of Interest: The authors declare no conflict of interest.

\section{Appendix A}
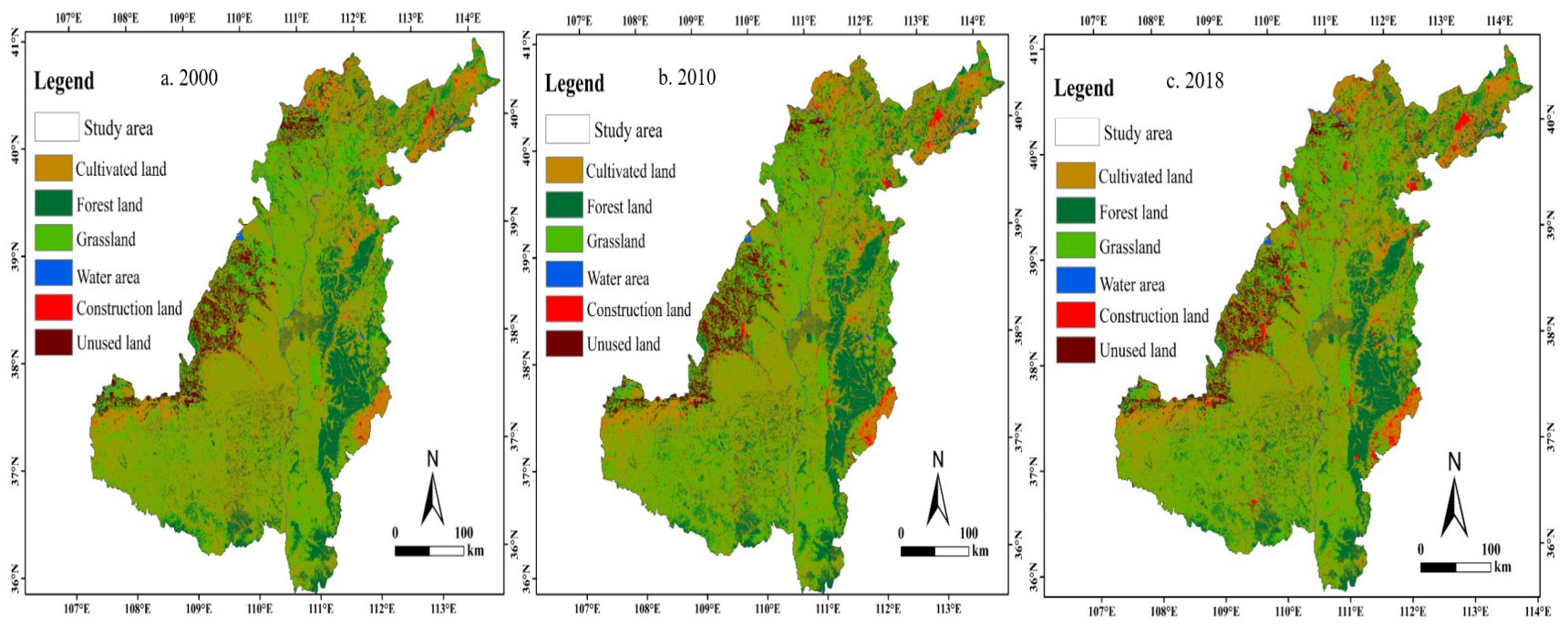

Figure A1. Land use types of the loess hilly-gully region in 2000 (a), 2010 (b) and 2018 (c).

\section{Appendix B}
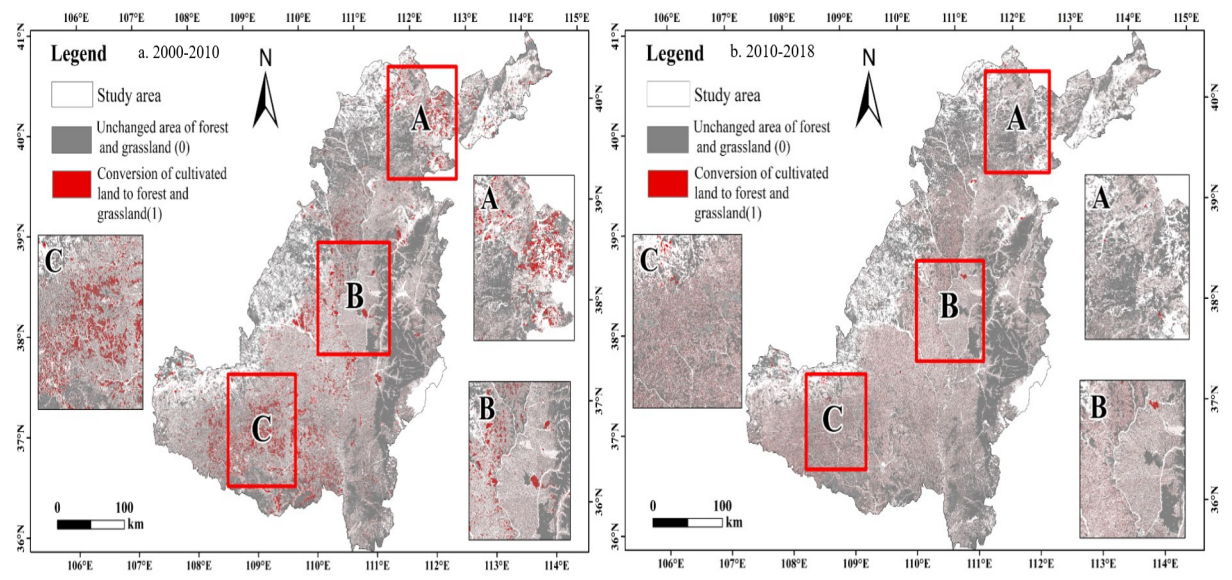

Figure A2. Conversion of cultivated land to forest and grassland in the loess hilly-gully region from 2000 to 2010 (a) and 2010 to 2018 (b). 


\section{Appendix C}
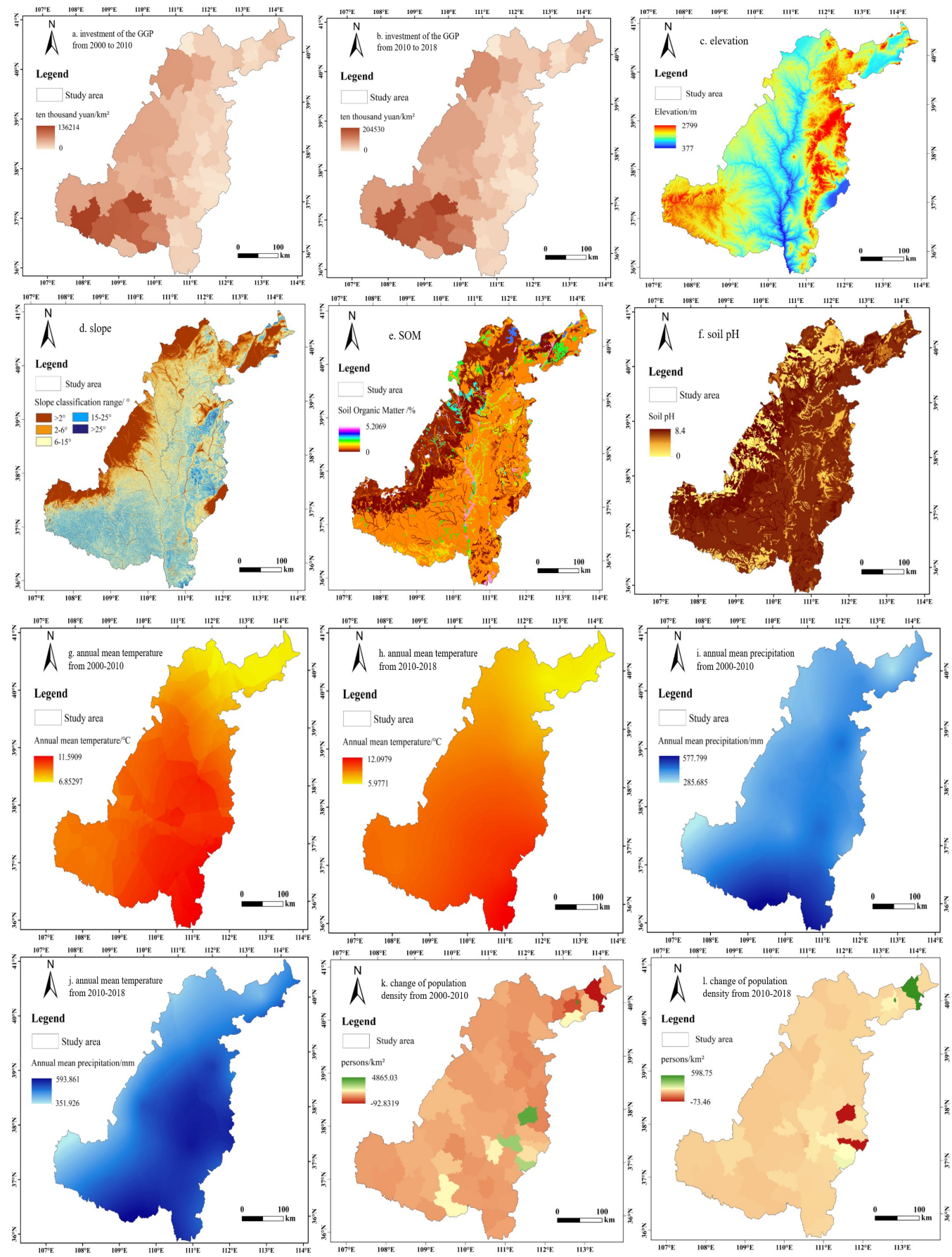

Figure A3. Cont. 

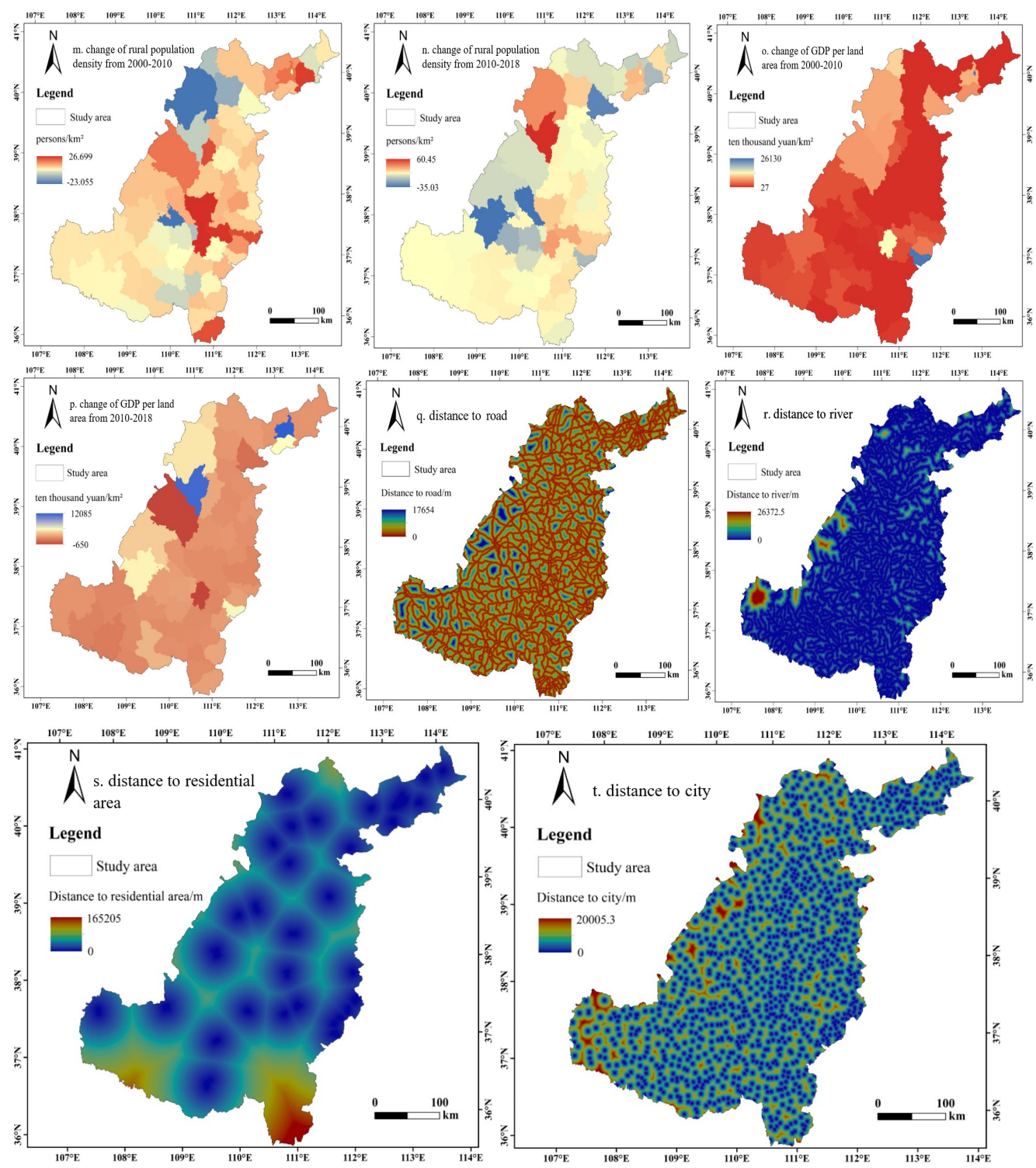

Figure A3. Driving factors of conversion of cultivated land to forest land and grassland from 2000 to 2010 and 2010 to 2018. All figures represent investment of the GGP from 2000 to 2010 (a); investment of the GGP from 2010 to 2018 (b); elevation (c); slope (d); soil organic matter (e); soil pH (f); annual mean temperature from 2000 to 2010 (g); annual mean temperature from 2010-2018 (h); annual mean precipitation from 2000 to 2010 (i); annual mean precipitation from 2010-2018 (j); change of population density from 2000 to 2010 (k); change of population density from 2010 to 2018 (l); change of rural population density from 2000 to 2010 (m); change of rural population density from 2010-2018 (n); change of GDP per land area from 2000 to 2010 (o); change of GDP per land area from 2010 to 2018 (p); distance to road (q); distance to river (r); distance to residential area (s); distance to city (t).

\section{References}

1. Vitousek, P.M.; Mooney, H.A.; Lubchenco, J.; Melillo, J.M. Human Domination of Earth's Ecosystems. Science 1997, 277, 494-499. [CrossRef]

2. Liu, J.G.; Diamond, J. China's environment in a globalizing world. Nature 2005, 435, 1179-1186. [CrossRef] [PubMed]

3. Yin, R.S.; Liu, C.; Zhao, M.J.; Yao, S.B.; Liu, H. The implementation and impacts of China's largest payment for ecosystem services program as revealed by longitudinal household data. Land Use Policy 2014, 40, 45-55. [CrossRef]

4. Xu, J.T.; Yin, R.S.; Li, Z.; Liu, C. China's ecological rehabilitation: Unprecedented efforts, dramatic impacts, and requisite policies. Ecol. Econ. 2006, 57, 595-607. [CrossRef]

5. Bryan, B.A.; Gao, L.; Ye, Y.Q.; Sun, X.F.; Connor, J.D.; Crossman, N.D.; Stafford-Smith, M.; Wu, J.; He, C.; Yu, D.; et al. China's response to a national land-system sustainability emergency. Nature 2018, 559, 193-204. [CrossRef] 
6. Wang, G.Y.; Innes, J.L.; Lei, J.F.; Dai, S.Y.; Wu, S.W. China's Forestry Reforms. Science 2007, 318, 1556-1557. [CrossRef]

7. Liu, J.G.; Li, S.X.; Ouyang, Z.Y.; Tam, C.; Chen, X.D. Ecological and socioeconomic effects of China's policies for ecosystem services. Proc. Natl. Acad. Sci. USA 2008, 105, 9477-9482. [CrossRef]

8. Cao, S.X.; Chen, L.; Yu, X.X. Impact of China's Grain for Green Project on the landscape of vulnerable arid and semi-arid agricultural regions: A case study in northern Shaanxi Province. J. Appl. Ecol. 2009, 46, 536-543. [CrossRef]

9. NFGA (National Forestry and Grassland Administration). China Forestry Statistical Yearbook 2017; China Forestry Press: Beijing, China, 2018.

10. Peng, H.; Cheng, G.; Xu, Z.; Yin, Y.; Xu, W. Social, economic, and ecological impacts of the "Grain for Green” project in China: A preliminary case in Zhangye, Northwest China. J. Environ. Manag. 2007, 85, 774-784. [CrossRef] [PubMed]

11. Wang, Y.C.; Zhao, J.; Fu, J.W.; Wei, W. Effects of the Grain for Green Program on the water ecosystem services in an arid area of China-Using the Shiyang River Basin as an example. Ecol. Indic. 2019, 104, 659-668. [CrossRef]

12. Liang, Y.C.; Li, S.Z.; Feldman, M.W.; Daily, G.C. Does household composition matter? The impact of the Grain for Green Program on rural livelihoods in China. Ecol. Econ. 2012, 75, 152-160. [CrossRef]

13. Persson, M.; Moberg, J.; Ostwald, M.; Xu, J.T. The Chinese Grain for Green Programme: Assessing the carbon sequestered via land reform. J. Environ. Manag. 2013, 126, 142-146. [CrossRef] [PubMed]

14. Fan, M.; Xiao, Y.T. Impacts of the grain for Green Program on the spatial pattern of land uses and ecosystem services in mountainous settlements in southwest China. Glob. Ecol. Conserv. 2020, 21, e00806. [CrossRef]

15. Betru, T.; Tolera, M.; Sahleb, K.; Kassa, H. Trends and drivers of land use/land cover change in Western Ethiopia. Appl. Geogr. 2019, 104, 83-93. [CrossRef]

16. Lambin, E.F.; Turner, B.L.; Geist, H.J.; Agbola, S.B.; Angelsen, A.; Bruce, J.W.; Coomes, O.T.; Dirzo, R.; Fischer, G.; Folke, C.; et al. The causes of land-use and land-cover change: Moving beyond the myths. Glob. Environ. Chang. 2001, 11, 261-269. [CrossRef]

17. Tilman, D.; Fargione, J.; Wolff, B.; D’Antonio, C.; Dobson, A.; Howarth, R.; Schindler, D.; Schlesinger, W.H.; Simberloff, D.; Swackhamer, D. Forecasting agriculturally driven global Environmental Change. Science 2001, 292, 281-284. [CrossRef]

18. Gao, P.; Niu, X.; Wang, B.; Zheng, Y.L. Land use changes and its driving forces in hilly ecological restoration area based on gis and rs of northern china. Sci. Rep. 2015, 5, 11038. [CrossRef]

19. Bicudo da Silva, R.F.; Millington, J.D.A.; Moran, E.F.; Batistella, M.; Liu, J. Three decades of land-use and land-cover change in mountain regions of the Brazilian Atlantic Forest. Landsc. Urban. Plan. 2020, 204, 103948. [CrossRef]

20. Wang, J.Y.; Liu, Y.S.; Liu, Z.G. Spatio-Temporal Patterns of Cropland Conversion in Response to the "Grain for Green Project" in China's Loess Hilly Region of Yanchuan County. Remote Sens. 2013, 5, 5642-5661. [CrossRef]

21. Zhou, D.C.; Zhao, S.Q.; Liu, S.G.; Zhang, L.X. Modeling the effects of the Sloping Land Conversion Program on terrestrial ecosystem carbon dynamics in the Loess Plateau: A case study with Ansai County, Shaanxi province, China. Ecol. Model. 2014, 288, 47-54. [CrossRef]

22. Chen, H.; Kenyon, J.M.; Carr, D.L.; Liang, X.Y. Land cover and landscape changes in Shaanxi Province during China's Grain for Green Program (2000-2010). Environ. Monit. Assess. 2015, 187, 644. [CrossRef] [PubMed]

23. Wang, B.; Zhang, Z.Q. Land use change driven by Sloping Land Conversion Program in typical watershed on Loess Plateau and its rationality evaluation. Trans. Chin. Soc. Agric. Eng. 2017, 33, 235-245.

24. Li, S.; Wang, T.; Yan, C.Z. Assessing the Role of Policies on Land-Use/Cover Change from 1965 to 2015 in the Mu Us Sandy Land, Northern China. Sustainability 2017, 9, 1164. [CrossRef]

25. Wang, C.; Zhen, L.; Du, B.Z. Assessment of the impact of China's Sloping Land Conservation Program on regional development in a typical hilly region of the loess plateau-A case study in Guyuan. Environ. Dev. 2017, 21, 66-76.

26. Wang, H.; Liu, G.H.; Li, Z.S.; Ye, X.; Fu, B.J.; Lu, Y.H. Analysis of the Driving Forces in Vegetation Variation in the Grain for Green Program Region, China. Sustainability 2017, 9, 1853. [CrossRef]

27. Qiu, L.; Wu, Y.; Wang, L.; Lei, X.; Liao, W.; Hui, Y.; Meng, X. Spatiotemporal response of the water cycle to land use conversions in a typical hilly-gully basin on the Loess Plateau, China. Hydrol. Earth Syst. Sci. 2017, 21, 6485-6499. [CrossRef]

28. Zeng, L.; Li, J.; Zhou, Z.X.; Yu, Y.Y. Optimizing land use patterns for the Grain for Green Project based on the efficiency of ecosystem services under different objectives. Ecol. Indic. 2020, 114, 106347. [CrossRef]

29. Liu, J.Y.; Wu, Y.; Wang, L.; Lei, X.; Liao, W.; Hui, Y.; Meng, X. Spatial patterns and driving forces of land use change in China during the early 21st century. J. Geogr. Sci. 2010, 20, 483-494. [CrossRef]

30. Huang, S.L.; Zhou, H.J.; Wang, J.G.; Wang, Y.Y. Driving forces of returning cultivated land to forest and grass in China at different scales. J. Arid Land Resour. Environ. 2010, 2010. 24, 113-116.

31. Du, Y.; Zhang, D.J.; Yao, S.B. Analysis of the Driving Forces of SLCP Based on the weights of Evidence Model-A Case Study of Wuqi, Shaanxi Province. Res. Soil Water Conserv. 2017, 24, 320-326.

32. Liu, C.; Huo, Y.W.; Sun, P.L.; Xu, Y.Q.; Lu, L.H.; Huang, A. Changes in Cultivated Land and Influencing Factors before and after the Implementation of Grain for Green Project in Zhangjiakou City. J. Nat. Resour. 2018, 33, 1806-1820.

33. Yin, R.S.; Xiang, Q.; Xu, J.T.; Deng, X.Z. Modeling the Driving Forces of the Land Use and Land Cover Changes Along the Upper Yangtze River of China. Environ. Manag. 2010, 45, 454-465. [CrossRef]

34. Shi, M.Y.; Yin, R.S.; Lu, H.D. An empirical analysis of the driving forces of forest cover change in northeast China. For. Policy Econ. 2017, 78, 78-87. [CrossRef] 
35. Liu, Y.S.; Feng, W.L.; Li, Y.R. Modern agricultural geographical engineering and agricultural high-quality development: Case study of loess hilly and gully region. Acta Geogr. Sin. 2020, 75, 2029-2046.

36. Liu, J.Y.; Ning, J.; Kuang, W.H.; Xu, X.L.; Zhang, S.W.; Yan, C.Z.; Li, R.D.; Wu, S.X.; Hu, Y.F.; Du, G.M.; et al. Temporal and spatial patterns and new features of land use change in China from 2010 to 2015. J. Geogr. Sin. 2018, 73, 789-802.

37. Liu, J.Y.; Kuang, W.H.; Zhang, Z.X.; Xu, X.L.; Qin, Y.W.; Ning, J.; Zhou, W.C.; Zhang, S.W.; Li, R.D.; Yan, C.Z.; et al. Basic characteristics and spatial pattern of land use change in China since the late 1980s. J. Geogr. Sin. 2014, 69, 3-14.

38. Liu, J.Y.; Zhang, Z.X.; Xu, X.L.; Kuang, W.H.; Zhou, W.C.; Zhang, S.W.; Li, R.D.; Yan, C.Z.; Yu, D.S.; Wu, S.X.; et al. Analysis of the spatial pattern and driving forces of land use change in China in the early 21st century. J. Geogr. Sin. 2009, 64, 1411-1420.

39. Liu, J.Y. China Resources and Environment Remote Sensing Macroscopic Survey and Dynamic Research; China Science Technology Press: Beijing, China, 1996.

40. Wang, X.L.; Bao, Y.H. Study on the methods of land use dynamic change research. Prog. Geogr. 1999, $18,81-87$.

41. Bell, E.J. Markov analysis of land use change-An application of stochastic processes to remotely sensed data. Socio-Econ. Plan. Sci. 1974, 8, 311-316. [CrossRef]

42. Zheng, J.K.; Yu, X.X.; Jia, G.D.; Xia, B. Dynamic evolution of the ecological service value based on lucc in miyun reservoir catchment. Trans. Chin. Soc. Agric. Eng. 2010, 26, 315-320.

43. Draper, N.R.; Smith, H. Applied Regression Analysis; John Wiley and Sons: New York, NY, USA, 1981.

44. Geoghegan, J.; Villar, S.C.; Klepeis, P.; Mendoza, P.M.; Ogneva-Himmelberger, Y.; Chowdhury, Y.Y.; Turner, B.L., II; Vance, C. Modeling tropical deforestation in the southern Yucatan peninsular region: Comparing survey and satellite data. Agric. Ecosyst. Environ. 2001, 85, 25-46. [CrossRef]

45. Hosmer, D.W.; Lemeshow, S. Applied Regression Analysis; ohn Wiley and Sons: New York, NY, USA, 1989.

46. Ludeke, A.K.; Maggio, R.C.; Reid, L.M. An analysis of anthropogenic deforestation using logistic regression and GIS. J. Environ. Manag. 1990, 31, 247-259. [CrossRef]

47. Zhou, D.C.; Zhao, S.Q.; Zhu, C. The Grain for Green Project induced land cover change in the Loess Plateau: A case study with Ansai County, Shanxi Province, China. Ecol. Indic. 2012, 23, 88-94. [CrossRef]

48. Xu, J.; Cao, Y. Efficiency and Sustainability of Converting Cropland to Forest and Grassland in The Western Region. In Implementing the Natural Forest Protection Program and the Sloping Land Conversion Program: Lessons and Policy Implications CCICED-WCFGTF; China Forestry Publishing House: Beijing, China, 2002.

49. Zhao, A.Z.; Zhang, A.L.; Lu, C.Y.; Wang, D.L.; Wang, H.F.; Liu, H.X. Spatiotemporal variation of vegetation coverage before and after implementation of Grain for Green Program in Loess Plateau. China. Ecol. Eng. 2017, 104, 13-22. [CrossRef]

50. Yang, H.Y.; Zhang, G.G.; Zhang, B.J. Growth Characteristics of Typical Plant Communities on Gully Slopes in the Loess Hilly-Gully Region. Res. Soil Water Conserv. 2019, 26, 62-67.

51. Zhong, L.N.; Wang, J.; Zhao, W.W. Comparative analysis of the effect of rainfall pattern and land use pattern on soil erosion in different-scale watersheds: A case study in hilly and gully area of the Loess Plateau. Acta Geogr. Sin. 2017, 72, $432-443$.

52. Feng, Z.; Yang, Y.; Zhang, Y.; Zhang, P.; Li, Y. Grain-for-green policy and its impacts on grain supply in West China. Land Use Policy 2005, 22, 301-312. [CrossRef]

53. Long, H.; Heilig, G.K.; Wang, J.; Li, X.; Luo, M.; Wu, X.; Zhang, M. Land use and soil erosion in the upper reaches of the Yangtze River: Some socio-economic considerations on China's Grain-for-Green programme. Land. Degrad. Dev. 2006, 17, 589-603. [CrossRef]

54. Zhao, J. The creation of farmland by gully filling on the Loess Plateau: A double-edged sword. Environ. Sci. Technol. 2014, 48, 883-884.

55. Zhang, Y.; Xue, J.H.; Zhang, X. The Impact of the Policy of Returning Farmland to Forest on Farmers' Income and Its Mechanism. Rural Econ. 2019, 6, 130-136.

56. Hu, C.X.; Fu, B.J.; Chen, L.D.; Gulinck, H. Farmer's attitudes towards the Grain-for-Green programme in the Loess hilly area, China: A case study in two small catchments. Catena 2003, 54, 303-316. [CrossRef]

57. Liu, Y.; Dong, Y. Factors Influencing Farmers Willingness to Participate in Grain for Green Project in the Post-program Era. Econ. Geogr. 2014, 34, 131-138.

58. Yang, L.; Fu, C. Spatial driving Force Analysis of Forest Land change in Ecological Barrier area of South Jiangxi. Geogr. Geo-Inf. Sci. 2018, 34, 58-62.

59. Cao, Q.W.; Wu, J.S.; Tong, D.; Zhang, X.N.; Lu, Z.Q.; Si, M.L. Drivers of regional agricultural land changes based on spatial autocorrelation in the Pearl River Delta, China. Resour. Sci. 2016, 38, 714-727.

60. Tang, K.L.; Zhang, K.L.; Lei, A.L. Critical slope gradient for compulsory abandonment of farmland on the hilly Loess Plateau. Chin. Sci. Bull. 1998, 43, 409-412. [CrossRef]

61. Li, D.C.; Huang, J.; Ma, C.B.; Xue, Y.D.; Gao, J.S.; Wang, B.R.; Zhang, Y.Z.; Liu, K.L.; Han, T.F.; Zhang, H.M. Soil Organic Matter Content and Its Relationship with $\mathrm{pH}$ and Bulk Density in Agricultural Areas of China. J. Soil Water Conserv. 2020, 34, $252-258$.

62. Liu, Y.; Lu, Y.H.; Zheng, H.F.; Chen, L.D. Application of regression tree in analyzing the effects of climate factors on NDVI in loess hilly area of Shaanxi Province. Chin. J. Appl. Ecol. 2010, 5, 1153-1158.

63. Chen, H.; Shi, Y.Y.; Ke, X.L.; Hao, J.M.; Chen, A.Q. Spatial optimization of land use based on the objective of coordinated ecological protection and economic development in Zhengzhou City. Resour. Sci. 2019, 41, 17-728.

64. Chen, Y.P.; Zhang, Y. Sustainable Model of Rural Vitalization in Hilly and Gully Region on Loess Plateau. S T Soc. 2019, 34, 708-716.

65. Jiang, N.; Bao, Q.; Song, Y.H. Driving Forces of Arable Land Change in Beijing Based on Logistic Regression Model. Arid Zone Res. 2017, 34, 1402-1409. 
66. Ke, S.F.; Zhao, T.Z. Empirical Analysis on Factors Influencing on Peasant Households' Willingness of Participation in Conversion of Cultivated Land to Forest Land Program. China Land Sci. 2008, 22, 27-33.

67. Rahman, S. Environmental impacts of technological change in Bangladesh agriculture: Farmers' perceptions, determinants, and effects on resource allocation decisions. Agric. Econ. 2005, 33, 107-116. [CrossRef]

68. Du, G.M.; Sun, X.B.; Liu, Y.S.; Zheng, H.Y.; Ma, R.H. Temporal and spatial-differentiation characteristics of ecological restoration in Loess Plateau. J. Geo-Inf. Sci. 2017, 19, 355-364.

69. Zhu, J.J.; Shi, X.Y. Analysis of Spatial Autocorrelation Patterns of Land Use and Influence Factors in Loess Hilly Region-A Case Study of Changhe Basin of Jincheng City. Res. Soil Water Conserv. 2018, 25, 234-241.

70. Mishra, A.K.; El-Osta, H.S.; Morehart, M.J.; Johnson, J.D.; Hopkins, J.W. Income, Wealth, and the Economic Services Programs: Accounting for Participant Heterogeneity. Environ. Econ. Policy 2002, 1, 235-254.

71. Zhang, H.M.; Zhu, Z.S.; Fan, Y.J. The impact of environmental regulation on the coordinated development of environment and economy in China. Nat. Hazards 2018, 91, 473-489. [CrossRef] 